\title{
Tropospheric temperature trends: history of an ongoing controversy
}

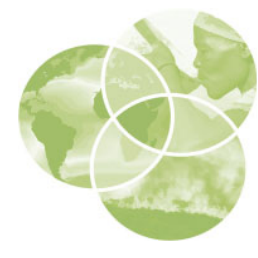

Peter W. Thorne, ${ }^{1,2 *}$ John R. Lanzante, ${ }^{3}$ Thomas C. Peterson, ${ }^{4}$

Dian J. Seidel ${ }^{5}$ and Keith P. Shine ${ }^{6}$

\begin{abstract}
Changes in atmospheric temperature have a particular importance in climate research because climate models consistently predict a distinctive vertical profile of trends. With increasing greenhouse gas concentrations, the surface and troposphere are consistently projected to warm, with an enhancement of that warming in the tropical upper troposphere. Hence, attempts to detect this distinct 'fingerprint' have been a focus for observational studies. The topic acquired heightened importance following the 1990 publication of an analysis of satellite data which challenged the reality of the projected tropospheric warming. This review documents the evolution over the last four decades of understanding of tropospheric temperature trends and their likely causes. Particular focus is given to the difficulty of producing homogenized datasets, with which to derive trends, from both radiosonde and satellite observing systems, because of the many systematic changes over time. The value of multiple independent analyses is demonstrated. Paralleling developments in observational datasets, increased computer power and improved understanding of climate forcing mechanisms have led to refined estimates of temperature trends from a wide range of climate models and a better understanding of internal variability. It is concluded that there is no reasonable evidence of a fundamental disagreement between tropospheric temperature trends from models and observations when uncertainties in both are treated comprehensively. @ 2010 Crown copyright WIREs Clim Change 20112 66-88 DOI: 10.1002/wcc. 80
\end{abstract}

\section{INTRODUCTION}

ince the earliest attempts to mathematically model $\checkmark$ the climate system's response to human-induced increases in greenhouse gases, ${ }^{1}$ a consistent picture of resulting atmospheric temperature trends has emerged. The surface and troposphere (the lowest $8-12 \mathrm{~km}$ ) warm with a local maximum trend in the

\footnotetext{
*Correspondence to: Peter.Thorne@noaa.gov

${ }^{1}$ Met Office Hadley Centre, FitzRoy Road, Exeter, UK

${ }^{2}$ Cooperative Institute for Climate and Satellites, NOAA National Climatic Data Center, 151 Patton Avenue, Asheville, NC, USA

${ }^{3}$ NOAA Geophysical Fluid Dynamics Laboratory, Forrestal Campus, US Route 1, PO Box 308, Princeton, NJ, USA

${ }^{4}$ NOAA National Climatic Data Center, 151 Patton Avenue, Asheville, NC, USA

${ }^{5}$ NOAA Air Resources Laboratory, 1315 East West Highway, Silver Spring, MD, USA

${ }^{6}$ Department of Meteorology, University of Reading, Earley Gate, PO Box 243, Reading, UK
}

DOI: $10.1002 /$ wcc. 80 upper levels in the tropics, while the stratosphere above cools (Figure 1).

In a 1990 paper, Spencer and Christy ${ }^{3}$ claimed that since the start of routine satellite temperature observations in 1979 there had been no tropospheric warming, despite apparently rapid surface warming. The paper raised questions about both the veracity of the surface temperature record and our understanding of the climate system's response to greenhouse gas increases, and it has been heavily cited in both scientific and political arenas. Taken at face value, these questions would have fundamental and farreaching implications for understanding of the climate system and efforts to mitigate projected climate change. The ensuing controversy has motivated several hundred research papers, two in-depth expert panel assessments, ${ }^{2,4}$ and numerous political hearings (see examples in supporting information), and has been discussed within all of the major Intergovernmental Panel on Climate Change (IPCC) scientific assessments. 
Zonal-Mean atmospheric temperature change in models

Trends computed over january 1979 to december 1999
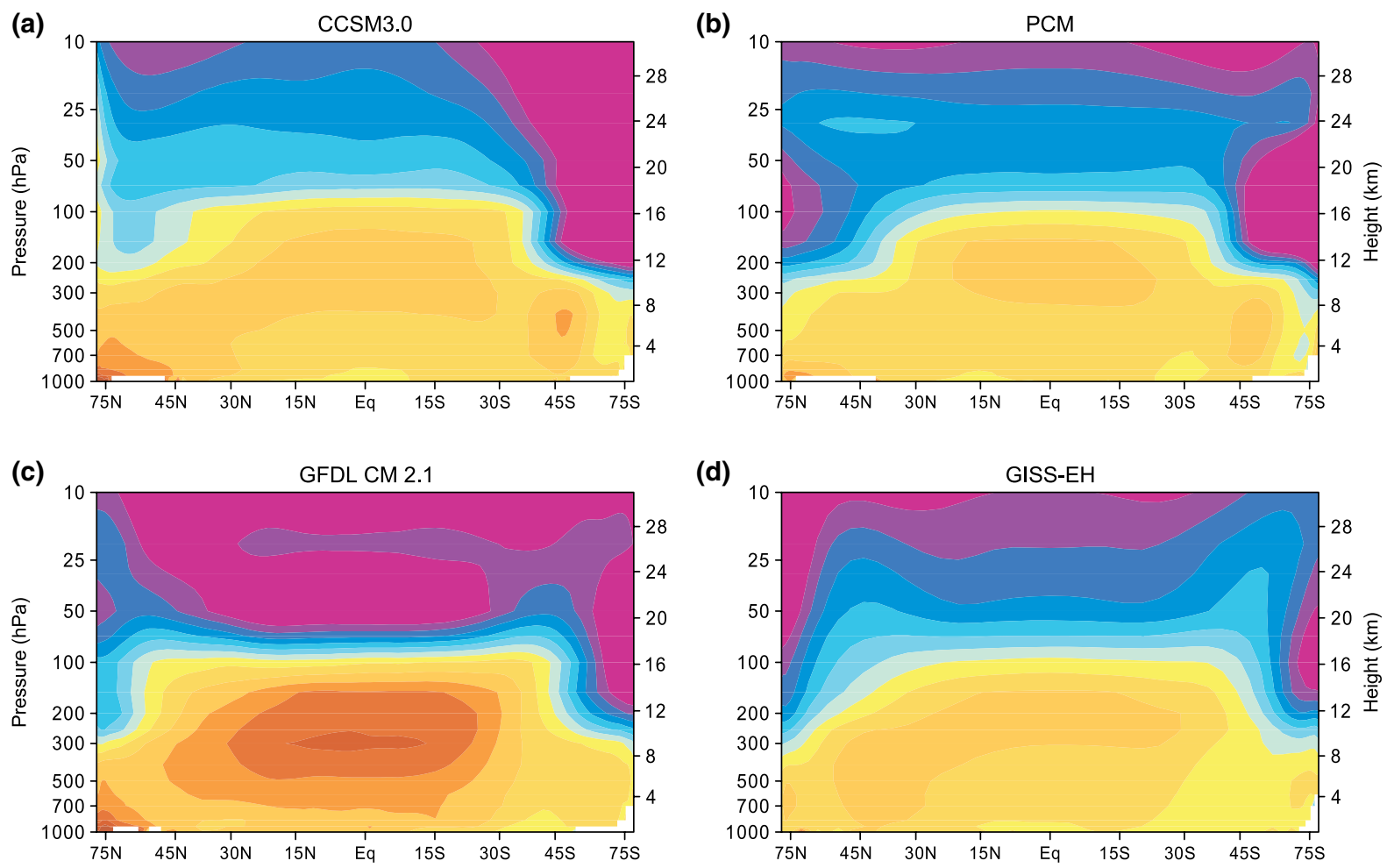

(d)
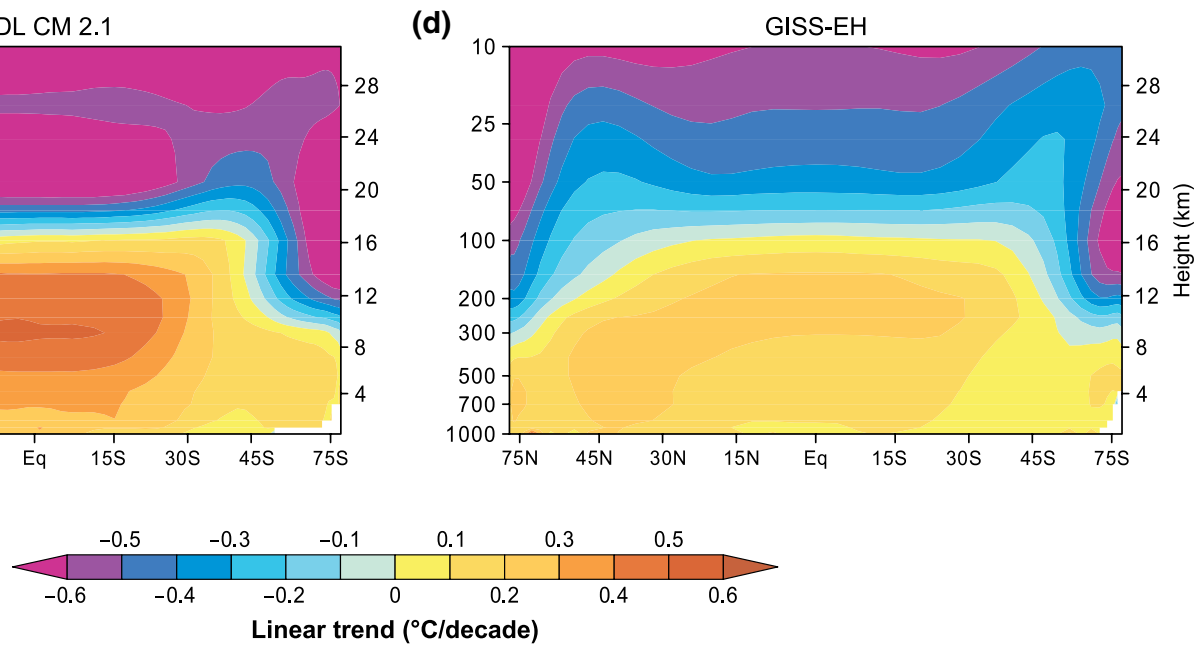

FIG URE 1 | Simulated 1979-1999 temperature trends from four modern-day climate models with representations of human-induced and natural forcings (see section on 'Modeling Temperatures in the Atmosphere'). All exhibit a warming troposphere with a maximum in the tropical upper troposphere and a cooling stratosphere, but with differences in trend patterns and magnitudes. Adapted from Climate Change Science Program Synthesis and Assessment Product 1.1.2

We present a history of the evolving understanding of atmospheric temperature trends, their uncertainties, and probable causes. The review focuses on peer-reviewed literature that assesses changes at the largest spatial scales (tropical, hemispheric, or global) to inform understanding of global climate changes. It is distinct from previous analyses in: (1) addressing the evolution of scientific issues rather than technical details; and (2) providing a historical perspective on the treatment of these issues by the scientific community.

As background, we present the scientific foundations for analyses of temperature trends and use of climate models to reconcile observations with competing hypotheses regarding likely causes. Our chronological review is organized by time periods corresponding to the IPCC assessments because of their important influence in interpreting and advancing the science. An annotated list of acronyms follows the main text. Supporting information is available online including a limited selection of political and mainstream science media developments which may be of interest to an interdisciplinary WIREs audience.

\section{OBSERVING AND MONITORING TEMPERATURES IN THE ATMOSPHERE}

All observing systems germane to this issue operate primarily to support weather forecasting, not climate monitoring and research. Most notably, frequent changes in instrumentation and practices have had a deleterious impact on the use of observations for the study of long-term climate changes by imparting substantial time-varying biases. Accounting for these 


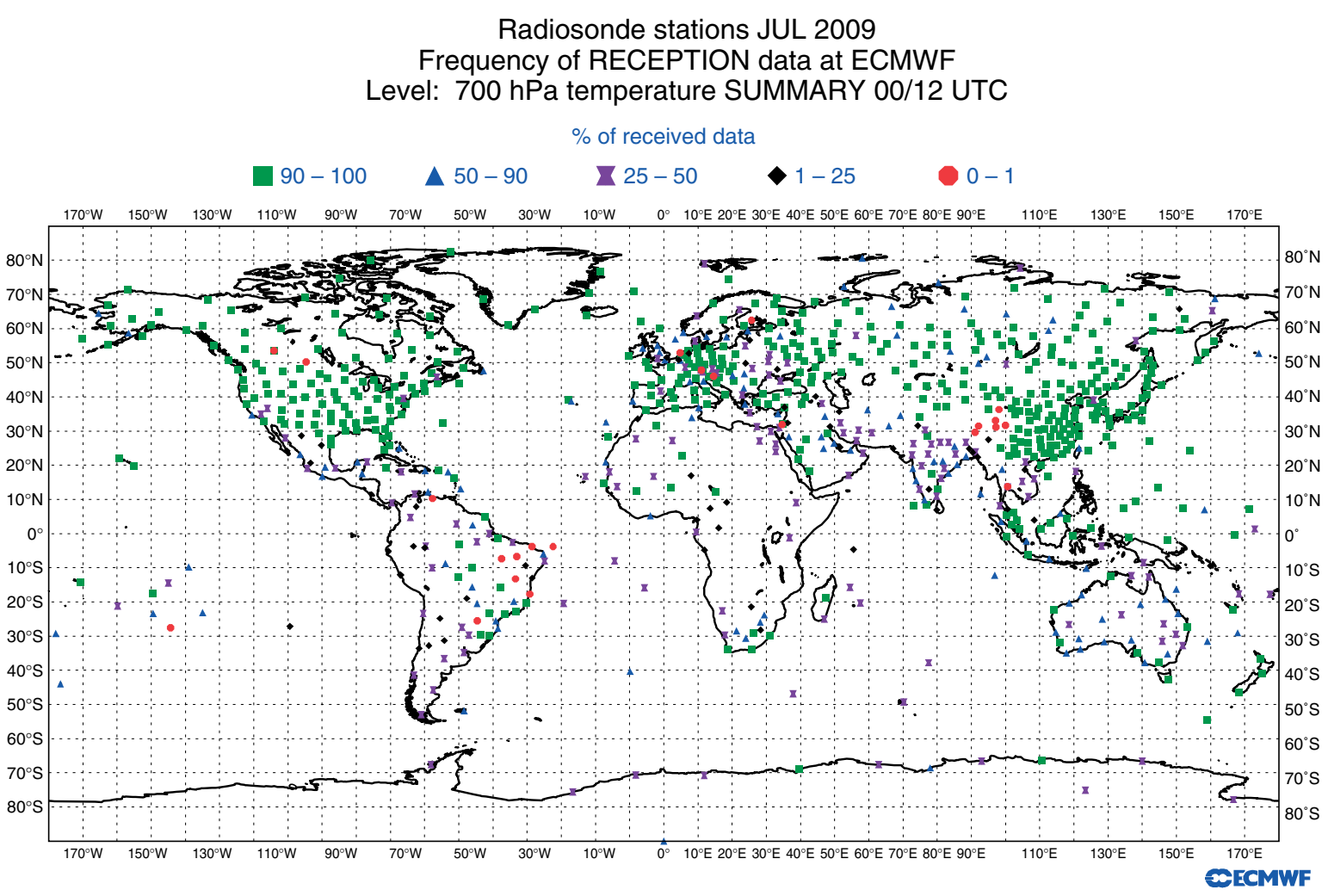

FIG URE 2 | Radiosonde station reporting performance, based on percentage of complete twice-daily coverage in July 2009 by the European Centre for Medium-Range Weather Forecasts. The poorer performance away from Northern Hemisphere mid-latitudes is typical of both contemporary and historical patterns. Figure courtesy of Antonio Garcia-Mendez and @ECMWF.

nonclimatic changes has led to problems in estimating trends.

Here we briefly introduce the three main data types (surface, radiosonde, and satellite measurements). The reader is referred to the supporting information for a more detailed discussion of their characteristics (S1.1-S1.3) and their strengths and weaknesses (S1.4) for use in characterizing long-term climate variations. A variety of steps are involved in creating a climate dataset from raw observations (S1.5), the most important of which is temporal homogenization to remove time-varying biases.

Over land, surface air temperature data come both from stations run by national meteorological services to support routine weather forecasts and from voluntary stations whose observations are received in delayed mode. Over ocean regions, Sea Surface Temperatures (SSTs) are usually used instead of air temperatures and have been collected by a diverse set of approaches with the dominant three being ships, buoys, and satellites.

Radiosondes are expendable instrument packages-typically including temperature, relative humidity, and pressure sensors-that are carried aloft by balloon, whose position is tracked for estimating horizontal wind. Radiosondes provide the longest available archive of free-atmospheric variables. ${ }^{5,6}$ The network (Figure 2 ) has evolved substantially over time and is concentrated over extratropical land masses of the Northern Hemisphere. Changes in radiosonde instruments (see example in Figure 3) and practices have led to time-varying biases which compromise trend analyses.

Unlike radiosondes, satellites do not make direct measurements of atmospheric temperature. Microwave Sounding Units (MSUs) measure upwelling microwave radiation emanating from the earth system, which varies in direct proportion to temperature. ${ }^{8}$ Interpreting MSU-derived temperatures is complicated because they represent a weighted average over a deep layer rather than temperature at a particular altitude. The MSU instrument channels produce data for different atmospheric layers, including the middle troposphere (MT or Channel 2, approximately surface to $18 \mathrm{~km}$ ) and the lower stratosphere (LS or Channel 4, approximately $15-35 \mathrm{~km}$ ). An undesirable property of MT is that it includes a small but climatically significant contribution from the stratosphere, which has been addressed by two approaches: a differencing of measurements for the 


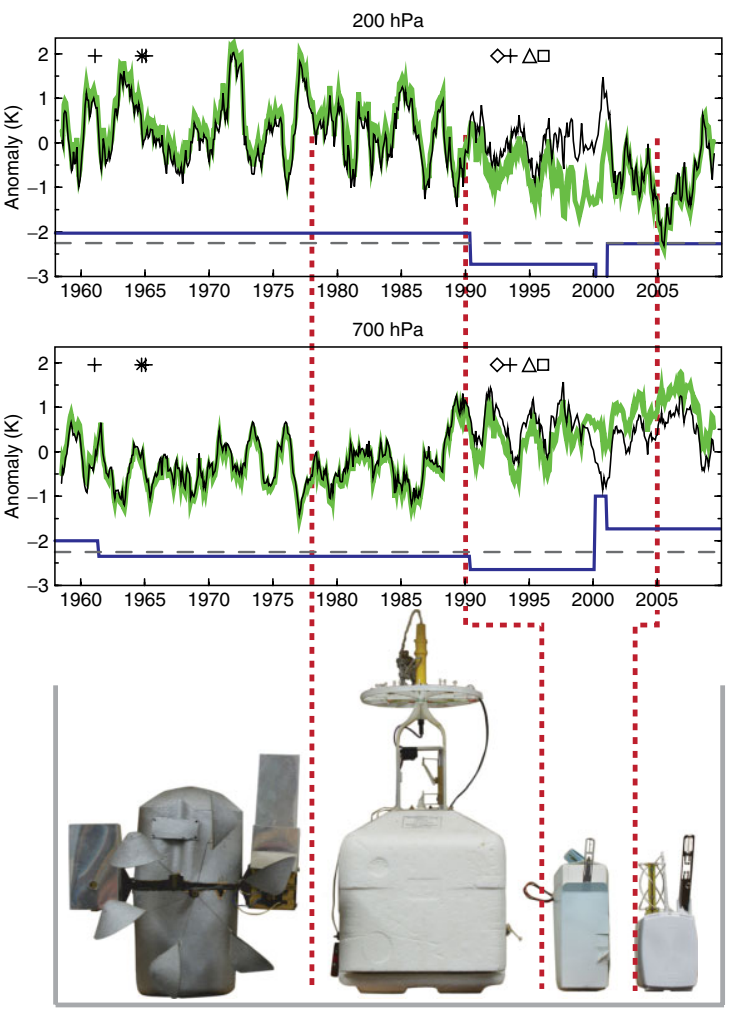

FIGURE 3 | Top 2 panels: monthly temperature anomalies (smoothed with a 13-point running average) during 1958-2009 from radiosonde observations at Camborne, Cornwall, UK, at $200 \mathrm{hPa}$ (near-tropopause) and $700 \mathrm{hPa}$ (lower-troposphere), including both raw (black) and adjusted (green) HadAT data. ${ }^{7}$ The smoothed difference series between the two shows the adjustments (offset by $2.25 \mathrm{~K}$ ). Bottom panel: the four radiosonde types used over this period (typical of UK-managed stations) are (left to right, with typical periods of operation): Phillips Mark Ilb (1950s-1970s); Phillips MK3 (mid 1970s to early 1990s); Vaisala RS-80 (early 1990s to 2005-2006); and Vaisala RS-92 (since 2005-2006). Dates of radiosonde changes (red dotted lines) are one sort of 'metadata event', ${ }^{5}$ others include:

cross-radiation correction procedure change; star-data cut-off change; diamond — change of pressure sensor; triangle — change of wind equipment; square - change of relative humidity sensor. Photos courtesy of Kevin Linklater, UK Met Office and background digitally enhanced for clarity by Sara Veasey NOAA NCDC.

MT channel at different view angles ${ }^{9}$ to obtain data representing the lower troposphere (LT), and statistical recombination (labeled ${ }^{*} \mathrm{G}$ ) of MT and LS to remove the LS influence ${ }^{10}$ (Figure 4). MSU was carried on a series of satellites starting in late 1978; it was superseded by Advanced MSU (AMSU) in 1998, although MSU continued to operate until 2005, offering a substantial overlap (Figure 5).

We briefly mention reanalyses, special hybrid data products created by combining as much observational data (including nontemperature data) as are available using data assimilation schemes. ${ }^{11-13}$

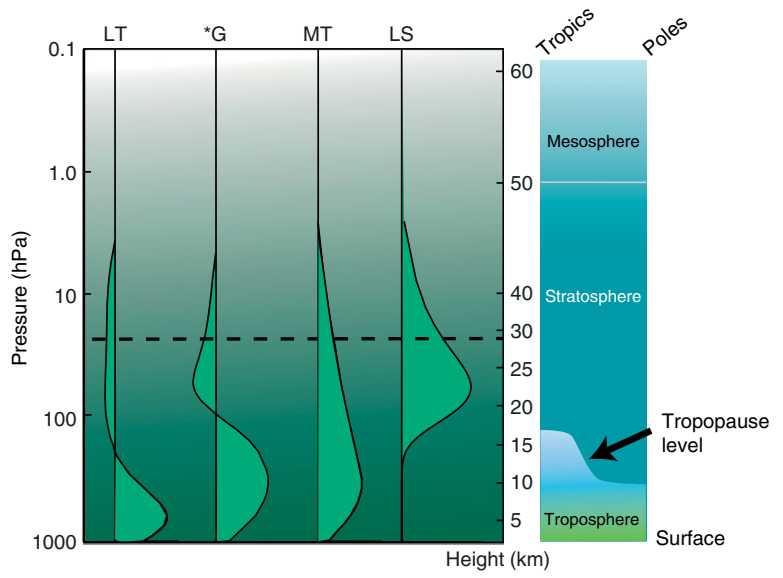

FIG URE 4 | Left: Vertical weighting functions for satellite products. Right: Schematic of atmospheric vertical structure and its latitudinal variation. The line at $30 \mathrm{hPa}$ indicates the typical maximum height of historical global radiosondes data coverage. Because LT and * $G$ involve combining data from other layers, they have negative weightings in parts of the atmospheric column. Adapted from Climate Change Science Program Synthesis and Assessment Product 1.1.2

Several erroneous findings using free-atmosphere trends from first and second generation reanalysis products have occurred (e.g., Refs 14-17). The recent Climate Change Science Program report on free-atmosphere temperatures ${ }^{2}$ concluded that 'trends arising from reanalyses [...] are not always reliable', ${ }^{18}$ and we consider such studies sparingly. We note, however, that the latest and future products may well be suitable (or indeed invaluable) for characterizing some free-atmosphere temperature changes. ${ }^{18-22}$

\section{MODELING TEMPERATURES IN THE ATMOSPHERE}

Numerical models vary in complexity depending on the number of separate, interacting subsystems

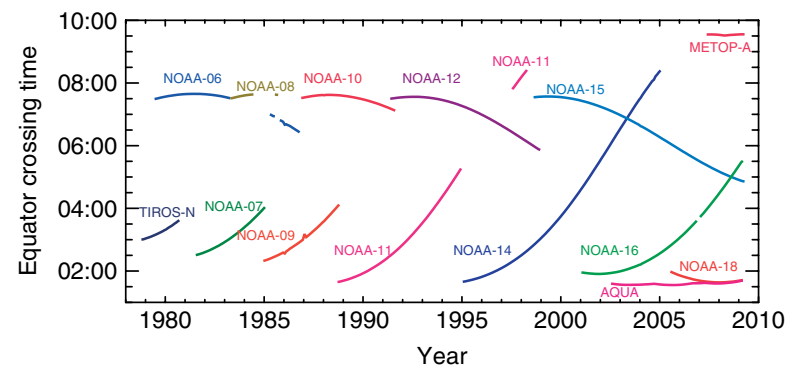

FIG URE 5 | Satellite Local Equatorial Crossing Times (LECTs) (pm for ascending/northward and am for descending/southward satellite orbits) for MSU instruments (TIROS-N to NOAA-14) and subsequent AMSU instruments (all other satellite platforms). Changes in LECTs typically accompany changes in orbital height and viewing geometry.Courtesy of Carl Mears, Remote Sensing Systems. 
and the manner by which processes are simulated. The hierarchy of climate models ranges from representation of the climate system by a single value (e.g. global-mean surface temperature) to threedimensional models with representations of the atmosphere, oceans, land surface, and chemical and biological processes. Models represent simplifications of a complex reality, dictated by knowledge limitations and practical constraints on computing.

General Circulation Models (GCMs) are threedimensional representations of the climate system. Early GCMs were relatively simple, but included the basic physical (but not biological or chemical) processes that underpin present-day understanding. GCMs gradually increased in sophistication (Figure 6) and resolution. The latest models include interactive chemistry, ecosystems, and carbon cycles, and enable representation of various climate system feedback mechanisms, although small time and space scale processes are still not explicitly modeled.

Models are a key bridge between theory and observations. They afford the opportunity to conduct 'what if' experiments not possible in the real-world climate system which evolves along a single trajectory. They provide estimates of how the climate system should behave (according to theoretical understanding) in response to changes external to the system, known as 'forcings'.

Radiative forcing drives much of long-term climate change and is a measure of the imbalance in the planetary energy budget, for example, due to increases in greenhouse gases (including carbon dioxide, ozone, and many others), changes in atmospheric aerosols, or solar variations. Changes in forcings can induce changes in the vertical as well as horizontal structure of temperature. Model simulations of past or future climates use best estimates of the historical or plausible future changes in forcings. The incorporation of forcings into climate models (Figure 6) has evolved significantly over time. ${ }^{23-25}$

Many groups have undertaken climate modeling using GCMs, and many conduct 'ensemble experiments' with a given model in which the forcings are identical, but the initial atmospheric state differs slightly for each ensemble member. Due to the 'butterfly effect' each ensemble member will have a unique trajectory. ${ }^{33}$ This divergence can be used to characterize the uncertainty of the model solutions resulting from 'internal variability' (such as occurrence and timing of El Niño), which is the natural variability of the system in the absence of changes in forcings. Although all climate models are derived from the same basic physical laws, the exact formulations and implementations vary among models. A multimodel ensemble of results therefore presents a set of plausible outcomes that help bracket our uncertainty. ${ }^{34}$

\section{EVOLVING UNDERSTANDING}

\section{Pioneering Model Projections and Observational Analyses from the late 1960s to Early 1990s}

As early as $1970,{ }^{35}$ the surface temperature responses to an $18 \%$ increase of atmospheric $\mathrm{CO}_{2}$ concentrations by 2000 and to doubling of $\mathrm{CO}_{2}$ were projected to be a warming of about 0.5 and $2 \mathrm{~K}$, respectively, albeit with considerable uncertainty. Two seminal studies by Manabe and Wetherald, ${ }^{1,27}$ provided the basic framework for expectations of the vertical structure of human-induced temperature change which still underpins current understanding. Their 1967 paper $^{1}$ was the first to point out that a stratospheric cooling would accompany the tropospheric warming when $\mathrm{CO}_{2}$ was increased, and the 1975 paper ${ }^{27}$ first simulated the enhanced warming in the tropical upper troposphere, relative to the surface, in response to a $\mathrm{CO}_{2}$ increase. They attributed this to the model representation of moist convective adjustment, clearly demonstrated by later studies using radiative-convective models. ${ }^{36,37}$ Subsequent GCM experiments ${ }^{38,39}$ revealed some variation among models regarding the amplification of the tropical upper-tropospheric warming, attributed mostly to the nature of the various convection schemes. ${ }^{40}$

During this period, observational analyses of temperature trends were limited in number and in their characterization of uncertainty. Long before satellite data were first used for climate trend analysis, researchers were analyzing in situ temperature observations. ${ }^{41-43}$ The 63 -station radiosonde network used by Angell ${ }^{41,42,44}$ revealed a 1958-1987 increase of about $0.3 \mathrm{~K}$ in the tropospheric $850-300 \mathrm{hPa}$ layer globally, much of it occurring in the late 1970s and early 1980s, consistent with global surface temperature changes. The upper troposphere-lower stratosphere 300-100 hPa layer showed cooling. Parker ${ }^{45}$ attempted to remove the nonclimatic influences from the data using a first-difference technique. ${ }^{46}$ Angell $^{47}$ noted that El Niño variability complicated the assessment of volcanic impacts on the troposphere.

Spencer and Christy ${ }^{3}$ of the University of Alabama in Huntsville (UAH) presented the first estimates from satellite data in Science. They made two major claims: that 'accurate long-term global temperature measurements can be obtained by satellites'; and that no obvious trend could be found in the 1979-1988 dataset, strongly implying that little 

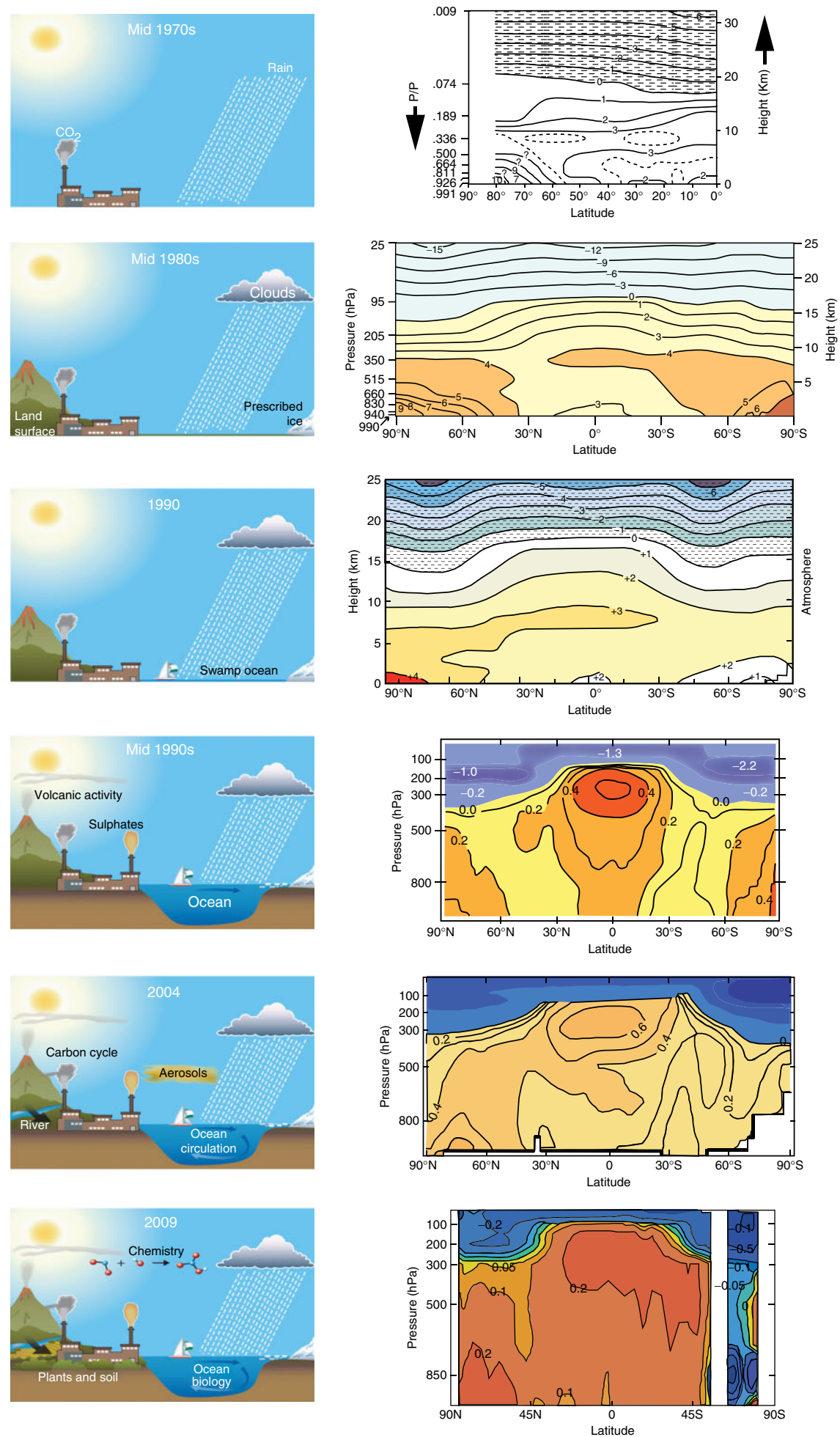

FIG URE 6 | Over several decades, increasing climate model complexity and increasingly realistic simulation of forcings (depicted at left) have led to little change in the expected pattern of atmospheric temperature change (right). Model representations are based on Treut et al. ${ }^{26}$ and courtesy Fiona Carroll. Zonal-mean temperature responses from progressive versions of the GFDL (top three, trends in K/century) and Hadley Centre (bottom three, trends in K/decade) models are directly from the literature, ${ }^{27-32}$ digitally enhanced for clarity only by Deb Misch NOAA/NCDC. 
if any global warming was occurring. Methodological details were expanded upon in a more technical article. ${ }^{48}$ A technical comment to Science ${ }^{49}$ raised several issues with the analysis and cautioned against making robust conclusions based upon a record of only a decade's duration. The original author team concurred that further investigation was merited, but disputed the posited importance of the issues raised. ${ }^{50}$ The first assessment report of the IPCC ${ }^{51}$ gave a rather different interpretation to that in the initial Science article. Comparing the MSU, surface and radiosonde temperature data during 1979-1988, it found high correlations and low root mean squared differences among them, and concluded that there is 'excellent agreement' given the short time period. The tropospheric and surface data agreement was termed 'surprisingly good, despite recent suggestions that it is poor'. The implication was that the tropospheric data agreed with the surface warming, the reality of which was not questioned by the report.

Early attempts to ascertain the causes of observed trends had mixed results. In 1982, Epstein ${ }^{52}$ analyzed Angell's radiosonde record through 1980 and failed to detect the expected temperature trends, but predicted that, with a longer data record, within 10 years they would be detectable, and that by jointly considering stratospheric and tropospheric changes 'a change that can be attributed to carbon dioxide increase should be detectable by 1986'. Parker ${ }^{53}$ examined temperature trends in radiosonde data over a 25 year period, but, failing to find the expected pattern of changes, concluded that another 20-35 years of observations would be required for its detection. Karoly detected statistically significant trends in Northern ${ }^{54}$ and Southern ${ }^{55}$ Hemisphere radiosonde stations in an index incorporating trends at six levels between 850 and $30 \mathrm{hPa}$. He noted both the consistency with the model projected greenhouse warming signal, and that other climate variations would also cause temperature changes of opposite sign in the troposphere and stratosphere. By 1990, the IPCC report chapter on detection of the greenhouse effect in the observations ${ }^{56}$ found 'broad agreement between the observations and equilibrium model simulations', with the main differences being related to the height at which tropospheric warming changes to stratospheric cooling.

\section{Early 1990s}

\section{Recognition of Data Limitations}

During the early 1990 s, Oort and Liu ${ }^{57}$ presented an updated radiosonde-based temperature dataset covering 1958-1989 with several differences in approach to that of Angell, ${ }^{44}$ the main one being use of the full global radiosonde network rather than a small selection of stations. Trends were generally similar in pattern, but with significantly different magnitudes. Parker and $\mathrm{Cox}^{58}$ and Gaffen ${ }^{59}$ identified (but did not attempt to remove) specific sources of time-varying biases (often called 'temporal inhomogeneity') in radiosonde temperature data. They noted the incompleteness of radiosonde station history 'metadata'. This latter situation had been only partially rectified by the global metadata compilation of Gaffen ${ }^{60}$ and remains to this day. ${ }^{5}$

Temporal inhomogeneity problems with MSU data were also starting to be recognized. Christy et al. ${ }^{61}$ attempted to remove a spurious warming signal associated with a sampling time drift in the NOAA 11 satellite (Figure 5) and a problem with the dynamic range on NOAA 12 . Other studies ${ }^{9,62-65}$ used comparisons with radiosonde data to support the homogeneity of the satellite data during 1979-1990, and a subsequent review paper by Christy ${ }^{66}$ suggested that all previously identified problems had been rectified.

\section{Identification of Climate Change Signals in Global Climate Models}

During this period, model-data comparisons were still mainly restricted to assessments of changes in global-mean temperatures. Climate signals unrelated to anthropogenic change complicated trend estimation, particularly over the short satellite record, and attempts were made to remove the effects of $\mathrm{El}$ Nino/Southern Oscillation (ENSO) and volcanoes from observational records, ${ }^{67,68}$ which reduced the discrepancy with model simulations. The observed difference between surface and tropospheric trends was found to be larger than either the climatemodel-simulated natural variability or the expected transient forcing response. ${ }^{69}$ The first studies to identify a climate change signal based on 'fingerprint' pattern matching techniques and using zonal-mean temperatures from radiosondes from 1958 onwards appeared, ${ }^{70,71}$ and one ${ }^{71}$ found that including stratospheric ozone depletion and sulphate aerosols changes in addition to $\mathrm{CO}_{2}$ improved the match.

\section{IPCC in 1995}

The observations chapter of the IPCC Second Assessment Report ${ }^{72}$ discussed in detail radiosonde data issues that might hamper reliable trend estimation. In contrast, MSU data were seen to 'have exhibited high precision' with the various biases in the data described as 'minimal', 'insignificant', or having 'been removed'. The global tropospheric trends from 1979 to May 1995 were reported as showing slight cooling: 
$-0.06^{\circ} \mathrm{C} /$ decade for $\mathrm{MSU}$ and $-0.07^{\circ} \mathrm{C} /$ decade for radiosondes. But after removing volcanic and ENSO effects, the time series showed a positive trend.

The detection and attribution chapter ${ }^{73}$ compared the observed pattern of stratospheric cooling and tropospheric warming (after removing ENSO and volcanic signals) with model simulations and concluded that 'there is no serious inconsistency between the most recent model predictions and MSU-based trend estimates'. However, it noted that the MSU period of record was relatively short. For detection and attribution, a sufficiently long record is required for any underlying signal to become distinct from 'noise' introduced by natural climate variability. To this end, work $^{70,71}$ with the longer radiosonde record was critical in forming the conclusion that 'The balance of evidence suggests a discernable buman influence on global climate'.

\section{Late 1990s}

\section{Identification of Specific Radiosonde and MSU Data Problems}

The late 1990s witnessed a growing recognition of radiosonde and MSU data homogeneity problems and concerted efforts by several groups to correct them. The Hadley Centre Radiosonde Temperature $(\operatorname{HadRT})^{58,74}$ dataset was the first global radiosonde product to incorporate homogeneity adjustments, applied at upper levels only and solely from 1979, based upon MSU LS data. ${ }^{63}$ The Comprehensive Aerological Reference Dataset (CARDS) project compiled all available raw radiosonde records ${ }^{75}$; a subset provided optimized spatial and temporal coverage. ${ }^{76}$ An auxiliary Monthly Aerological Data Set offered monthly average values, ${ }^{77}$ and a gridded version was created at the All-Russian Research Institute of Hydrometeorological Information (RIHMI). ${ }^{78}$ The original 63-station 'Angell network' ${ }^{42}$ was still in use, ${ }^{79,80}$ but nine tropical stations were eliminated because of data concerns. ${ }^{80}$

Luers and Eskridge ${ }^{81}$ attempted a novel radiosonde data homogeneity adjustment approach using thermodynamic properties of each type of radiosonde. Although promising in theory, independent validation was not possible. ${ }^{82}$ Gaffen et al. ${ }^{83}$ explored several different approaches for identifying and adjusting artificial discontinuities, highlighting the difficulty of the endeavor and the sensitivity of the resulting trends.

Although UAH remained the only readily available MSU dataset, four versions $\left(\mathrm{A},{ }^{9,62} \mathrm{~B},{ }^{61} \mathrm{C},{ }^{84}\right.$ and $\mathrm{D}^{85}$ ) were created during the 1990 s. Diagnostic studies by other investigators ${ }^{86-89}$ provided a basis for version D. Wentz and Schabel's ${ }^{87}$ finding of an orbital decay effect and its implications of an artificial cooling impact upon the UAH TLT record gained significant prominence in Nature and Science. ${ }^{90-93}$

For the first time, a group produced temperature series and trend estimates from MSU data independently of UAH, ${ }^{88,89,94}$ and they showed substantially more tropospheric warming than UAH. However, this dataset was not updated so had limited utility.

Surface temperatures, radiosonde temperatures, and climate model output were used to make inferences regarding the UAH record. Two artificial discontinuities were claimed in the tropical MSU series ${ }^{95-98}$ and disputed by UAH using radiosonde data. ${ }^{99}$

\section{Identification of the Causes of Observed Tropospheric Changes}

Studies comparing modeled and observed temperature changes during the late 1990s were more sophisticated and examined the effects of different climate forcings. Comparing zonal-mean temperature changes using HadRT $^{74}$ data from 1960 onwards with GCM output, two studies ${ }^{30,100}$ found identifiable 'fingerprints' of greenhouse gases and ozone depletion. Another ${ }^{101}$ evaluated the realism of GCM internal variability vis$\grave{a}$-vis HadRT and found deficiencies in the stratosphere but reasonable agreement in the troposphere, as well as tentative evidence for volcanic and solar influences. Analysis of an atmosphere-only GCM found that the influence of observed SSTs alone could not explain the observed HadRT signal but including greenhouse gases and other forcings yielded consistency. ${ }^{102}$

Several studies concluded that the larger rate of surface warming than in the troposphere over the satellite era was real and discussed possible physical mechanisms. ${ }^{4,103-105}$ Others highlighted the underlying uncertainties due to various factors such as horizontal, vertical and temporal sampling, spatial averaging, statistical sampling issues, choice of dataset, etc. ${ }^{104,106-109}$ Explicit examination of the difference between surface and tropospheric trends in the tropics uncovered low frequency variations, along with a difference in the sign of the trend during and prior to the satellite era. ${ }^{109,110}$

\section{IPCC in 2001}

The IPCC Third Assessment Report built upon the U.S. National Research Council (NRC) report ${ }^{4}$ which had concluded that the surface really was warming relative to the troposphere. IPCC concurred, acknowledged that all measuring systems 'contain significant time-varying biases', ${ }^{105}$ and described advantages and disadvantages of each. The detection and attribution chapter ${ }^{111}$ acknowledged the difficulties involved 
in analyzing this problem and reconciling inconsistencies between the observed and modeled vertical patterns of temperature change. It concluded that 'nevertheless, all the studies indicate that anthropogenic factors account for a significant part of recent observed changes, whereas internal and naturally forced variations alone, at least as simulated by current models, cannot explain the observed changes'. The studies referred to had almost invariably considered the longer radiosonde era and not the satellite era.

\section{Early 2000s}

The early 2000s saw a rapid multiplication of approaches to homogenizing long-term temperature observations and resulting global datasets. Detection studies were refined, and observational uncertainties were identified as the primary explanation for discrepancies between models and observations.

\section{Attempts to Homogenize Observational Data and Emergence of Multiple Analyses}

A workshop bringing together groups developing methods to identify and remove inhomogeneities in radiosonde data ${ }^{112}$ set a cautionary tone, having revealed that different methods applied to real-life test cases found only limited agreement. Although most failed to progress beyond the development phase, two new radiosonde temperature datasets emerged. The LKS effort ${ }^{113,114}$ was the first to make adjustments independent of satellite data, over a globallydistributed network, for both tropospheric and stratospheric levels. Post-construction comparisons with MSU temperatures suggested improved trend characterization. They concluded that unadjusted radiosondes suffer world-wide from a spurious cooling bias throughout the atmospheric column. However, since the subjective, labor-intensive approach did not lend itself readily to updates, a new dataset was created by extending the LKS product which terminated in 1997. The first-difference method of dataset construction, previously successfully employed for surface data, ${ }^{46}$ was adapted ${ }^{115}$ to create a new NOAA dataset: Radiosonde Atmospheric Temperature Products for Assessing Climate (RATPAC). ${ }^{116}$ The second effort was the Hadley Centre Atmospheric Temperatures (HadAT) product. $^{7}$ Unlike RATPAC, which was limited to 85 stations, HadAT utilized 676. HadAT adjustments were based on comparison of target station data with similar time series from suitable neighbor stations. This contrasts with LKS which was almost entirely dependent upon information local to a station. At a more fundamental level, creation of the quality-controlled Integrated Global Radiosonde Archive (IGRA) ${ }^{5}$ in place of CARDS was a major advance. Although without homogeneity adjustments, IGRA is now the highest-quality archive of long-term global radiosonde and pilot balloon soundings.

Analysis of differences between day and nighttime soundings by several investigators ${ }^{117-119}$ revealed systematic and geographically pervasive biases, including a suspicious relative daytime cooling globally, most notably in the tropics, with residual bias even after adjustment. ${ }^{120-122}$ Angell $^{123}$ found better trend agreement between the remaining network after eliminating nine tropical stations with suspect homogeneity from his original network of 63 .

Major developments with MSU temperature data included release of version 5.0 of the UAH product $^{124}$ with revised adjustments and incorporation of AMSU measurements. Most significant was the creation of MSU datasets by two new teams, Remote Sensing Systems (RSS) and a group from the University of Maryland (UMd). The RSS team initially created only MT and LS products, ${ }^{125}$ later adding LT. ${ }^{126}$ They uncovered an error in the UAH LT drift adjustment methodology, a correction for which resulted in UAH v5.1. ${ }^{127}$ Although this correction led to little overall change in global trends, it had a distinct latitudinal signature and revealed greater tropical warming and reduced mid to high latitude warming. The UMd team produced MT data ${ }^{128}$ which was subsequently revised. ${ }^{129,130}$

Although similar in many respects, the UAH and RSS approaches have two main differences, ${ }^{131}$ and in both cases RSS uses more data, while UAH applies constraints based on improving error characteristics. The MT trend difference between the two is mainly attributable to a difference in parameters derived for NOAA-9 which, due to premature failures had a particularly short overlap with adjacent satellites in the series. ${ }^{2}$ UMd used a fundamentally different, more physically-based approach, with a substantially different merging procedure from that of UAH and RSS. ${ }^{132}$ Such uncertainties in homogenization complicate assessment of climate trends. ${ }^{133}$ A confounding issue is the methodological differences in constructing MSU data products for different layers and the interpretation of the LT layer, with its large surface contribution. ${ }^{134}$

Although the stratospheric contribution to MT observations had long been recognized, work by $\mathrm{Fu}$ and co-workers ${ }^{10,135-138}$ set out to explicitly remove it by combining MT and LS to produce a measure $\left({ }^{*} \mathrm{G}\right)$, that is distinct from LT but has a similar vertical weighting function (Figure 4). Initial critical 
analysis of this method ${ }^{139}$ highlighted several issues. Application to model simulations ${ }^{140,141}$ suggested better agreement between observations and model and theoretical expectations regarding the surface versus troposphere differential warming, and revealed some inconsistencies in the UAH tropospheric products, although UAH criticized the approach. ${ }^{142}$

A comprehensive comparison of then-available upper-air datasets ${ }^{143}$ found better agreement for interannual climate signals than trends. The effects of regional variations in signals and of differing spatial sampling strategies were explored by several groups, ${ }^{104,144-146}$ as were the effects of dataset choice $^{147}$ and shifts in regional climate regimes ${ }^{148}$ on temperature trends.

\section{Refinement of Climate Change Detection Studies in the Troposphere}

Several studies compared HadRT data from 1958 onwards to GCM output. ${ }^{31,149-153}$ They all found strong evidence for a greenhouse gas fingerprint; some also found evidence for volcanic ${ }^{151-153}$ or solar ${ }^{150}$ influences. Responding to criticism that the asymmetry in trends between the troposphere and stratosphere dominated formal detection and attribution studies, ${ }^{154}$ Thorne et al. ${ }^{151,152}$ examined the troposphere in isolation and still detected a greenhouse gas signal. Trends in the newer HadAT observational analyses were found to be outside model estimates of natural variability, and anthropogenic effects were required to explain the observations. ${ }^{32}$

A comparison of UAH and HadRT with new GCM results from the NASA Goddard Institute for Space Studies yielded discrepancies in trend behavior, particularly in the tropics, but best overall agreement when the model was forced with natural and anthropogenic forcings. ${ }^{155}$ In contrast to earlier work, Michaels and Knappenberger ${ }^{156}$ argued that the timing of ENSO and volcanic events added a warming trend to the satellite record which, when accounted for, exacerbated apparent discrepancies with model expectations. Santer et al. pointed out the dangers of such analyses given that the timing of ENSO and volcanoes are correlated in the observed record. ${ }^{157}$ In a pair of papers, Douglass et al. ${ }^{158,159}$ invoked a first generation reanalysis as well as a dated subset of the available direct observations and argued for fundamental inconsistencies between model-based expectations and observed behavior over the satellite era. Lindzen and Giannitsis ${ }^{160}$ hypothesized that the apparent discrepancy between observed and modeled behavior over the satellite era could be related to a delay in surface response to an atmospheric temperature jump in the mid-1970s.
Comparing the RSS and UAH MT records with GCMs, Santer et al. ${ }^{161}$ found the tropospheric fingerprint of greenhouse gases evident only in RSS, highlighting for the first time the importance of accounting for observational uncertainty. A satellite era analysis for the tropics ${ }^{25,162}$ found that all observations and climate models exhibited amplification of surface changes aloft on monthly to annual timescales, consistent with basic theory. However, on multidecadal timescales climate models conformed to this behavior, whereas all observational estimates except RSS damped rather than amplified the surface warming aloft. While this discrepancy was attributed to model deficiencies, to observational errors, or a combination of both, observational errors were concluded to be the most parsimonious explanation (Figure 7).

\section{IPCC 2007}

The Fourth Assessment Report of the IPCC made considerable use of the U.S. Climate Change Science Program report on understanding temperature trends in the lower atmosphere. ${ }^{2}$ This report, with authorship from many of the principal participants in the debate, had taken several years to create and spawned many significant papers. It concluded that there was no evidence for a discrepancy between surface and tropospheric temperature trends globally but that ambiguity remained in the tropics. The presence of substantial observational uncertainty in the tropics was posited as the most likely explanation. Similar to its 2001 discussion, IPCC stated in 2007 that 'there is agreement that the uncertainties about longterm change are substantial' ${ }^{163}$ and that 'it is difficult to make quantitatively defensible judgements as to which, if any, of the multiple, independently-derived estimates is closer to the true climate evolution'. Many sources of biases in the various datasets were discussed. It noted that radiosonde data since 1958 indicate tropospheric warming slightly exceeding surface warming. The chapter on Understanding and Attributing Climate Change ${ }^{164}$ focused largely on the tropical troposphere, ${ }^{25,162}$ and highlighted the value of a multimodel analysis to aid understanding.

\section{Late 2000s}

The last few years have witnessed even greater attention to radiosonde and MSU data homogeneity and the emergence of new approaches and data products. Modeling efforts have become more sophisticated. The basic conclusion that there is no discrepancy between model and observed trends is supported by the most recent work. 

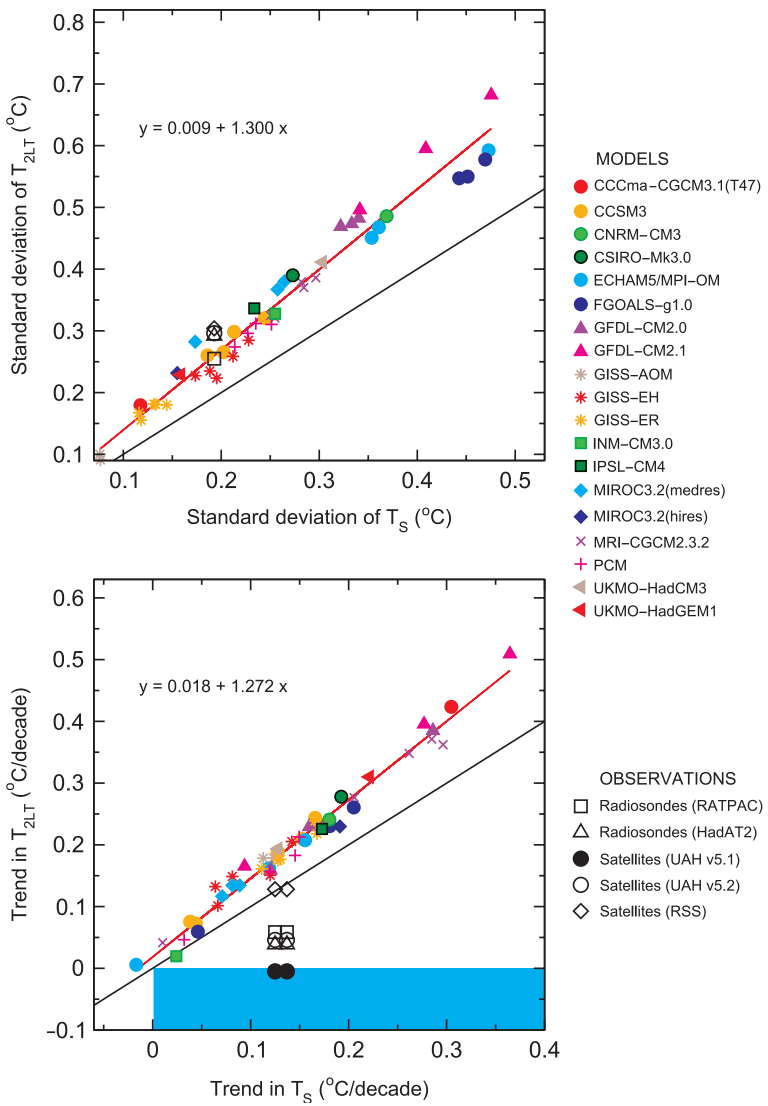

FIGURE 7| Tropical temperature behavior in observations and models (including those in Figure 1). Top panel characterizes month-to-month surface and LT temperature variability; both observations and models show surface variability is amplified aloft (slope of the line fit to the model points $>1$-the black line). Lower panel repeats the analysis for temperature trends over the period 1979-1999; observations no longer agree with models, and all but RSS exhibit damping with height. Possible explanations are (1) a real mechanism that modulates long-term behavior that all models miss, or (2) residual nonclimatic influences in some or all the observations that substantially impact their long-term trend estimates. The Climate Change Science Program report concluded that the latter was the more likely explanation. ${ }^{25}$ Adapted from Climate Change Science Program Synthesis and Assessment Product 1.1.2

\section{Multiplicity of Homogenized Radiosonde and MSU datasets}

This period saw better exploration of uncertainties in current radiosonde datasets along with the creation of three new independent datasets that increased the apparent uncertainty in radiosonde temperature trend estimates. Automation of analysis procedures ${ }^{165}$ and creation of error models for evaluating their performance ${ }^{166}$ led to the conclusion that HadAT quite likely exhibits too little tropospheric warming over the satellite era, particularly in the tropics. A University of Vienna team used a novel homogenization approach ${ }^{167,168}$ involving ERA-40 reanalysis, ${ }^{12}$ on the premise that difference time series of radiosonde minus reanalysis background are sensitive indicators of changes in radiosonde biases. The detected breakpoints were adjusted with either the reanalysis field (RAOBCORE family of products ${ }^{167,168}$ ) or apparently homogeneous neighbor segments $\left(\mathrm{RICH}^{168}\right)$. Finally, another group led by Sherwood employed kriging, a method used commonly in the geostatistical community, to synergistically estimate real climate signals, missing data, and artificial breakpoints through an iterative procedure $\left(\mathrm{IUK}^{169}\right)$. Although they attained a measure of success for a global network of stations, they expressed concern over likely remaining spurious cooling biases in the deep tropics.

The Sherwood group also used radiosondemeasured winds through the thermal-wind relationship $^{170-172}$ to infer substantial tropical uppertropospheric warming. The strengths of this approach are that there have been fewer changes to radiosondes' wind measurement techniques than to temperature measurements, ${ }^{173}$ and artefacts in wind measurements are generally more easily identified and adjusted.

Over the satellite era those datasets considered in the 2007 IPCC report (RATPAC and HadAT) exhibit less tropospheric warming than any of the newer datasets at most levels (Figure 8). The apparent discrepancy with model behavior disappears if the newest datasets are used. The ensemble estimate from the automated HadAT experiments ${ }^{166}$ (not shown) also includes the expected model behavior. An analysis using a Bayesian selection criteria ${ }^{174}$ reinforced previous work ${ }^{175}$ that alternatives to a straight line fit may better describe the time series evolution.

For MSU, RSS undertook substantial data reprocessing to create version $3.2,{ }^{176,177}$ resulting in minor differences to their trend estimates and a quantification of the generally acceptable degree of agreement with available radiosonde tropospheric datasets. ${ }^{177}$ A NOAA group ${ }^{178,179}$ (STAR) introduced a new method to produce MT, and later LS, estimates based on simultaneous nadir overpass data near the poles. Because they should indicate the same temperature for a given scene, the simultaneous measurements by different satellites can be used to quantify the biases between them, although further adjustments are required. ${ }^{179}$ Trends derived from STAR show more warming within the troposphere than similar products produced by others (Figure 8 ).

A series of studies compared MSU and radiosonde data, locally or regionally. Christy and Norris ${ }^{181}$ concluded UAH LT, MT, and LS products were more reasonable than RSS products based on closer agreement with radiosondes operated by the 

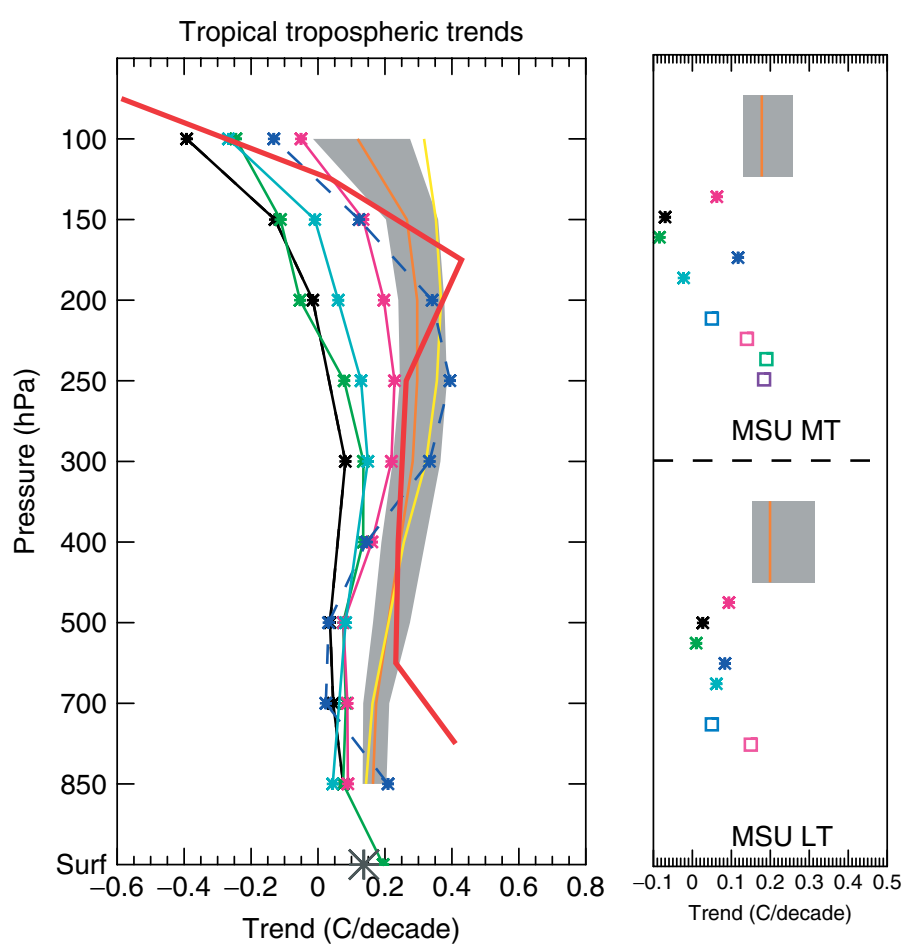

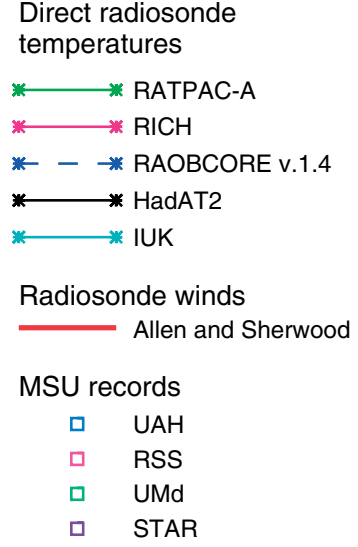

Surface change

* HadCRUT3

Model and theoretical expectations

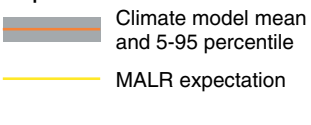

FIG URE 8 | Left: tropical tropospheric temperature trend estimates for 1979-2005 (K/decade) from adjusted radiosonde datasets and from models (derived by scaling the range of model amplification in Figure 7 by the HadCRUT3 surface trend ${ }^{180}$ ) and from moist-adiabatic lapse rate theory (MALR). ${ }^{162}$ Estimates from winds are from Allen and Sherwood. ${ }^{171}$ Right: same but for LT and MT layers and incorporating MSU time series estimates. The vertical displacement of the points in the right hand panels is for clarity only, and each point represents the average trend over the relevant MSU weighting function. The observations would fall within the model range if both the surface trend is accurate and the model amplification constraint applies in the real world.

United States, and Christy et al. ${ }^{182}$ drew similar conclusions for LT using tropical radiosonde stations. Christy and Norris ${ }^{183}$ confirmed these findings for Australian data. The RSS adjustment procedure for the transition from NOAA-11 to NOAA-12 was identified as the primary problem. Randall and Herman ${ }^{184}$ using radiosonde data and Bengtsson and Hodges ${ }^{20}$ using reanalyses came to similar findings independently. But these various studies also revealed other issues with the various MSU records considered. Satellite records were shown to be most uncertain when one or more satellites are drifting rapidly. ${ }^{181,183}$ A further issue with such comparisons is that they generally utilised raw radiosonde data or adjusted RATPAC or HadAT data, all of which subsequent research (see above) suggests retain a long-term cooling bias.

\section{A Focus upon Understanding the Tropical Troposphere}

Detailed comparisons of radiosondes since 1958 and GCMs ${ }^{185,186}$ indicated that the use of homogeneity-adjusted radiosonde data systematically improves agreement between models and observations, although even adjusted observations tended to show less warming or more cooling than GCMs. Forster et al. ${ }^{187}$ hypothesized that model deficiencies-insufficient ozone reduction in the tropical lower stratosphere and excessive effects of convection in the upper troposphere-may explain the apparent excessive long-term warming of the upper tropical troposphere in GCMs. Thorne et al. ${ }^{188}$ examined structural uncertainty in both GCMs ${ }^{189}$ and observed data over both the satellite and radiosonde eras, as well as choice of analysis period start and end dates, and concluded that uncertainties are large enough to preclude a fundamental difference between model and real-world tropical tropospheric amplification of warming. A claim by Douglass et al. ${ }^{190}$ that trends in tropical temperatures derived from models were substantially inconsistent with those from observations was refuted by Santer et al. ${ }^{191}$ using newer observational datasets and correcting several methodological flaws. By comparing temperature and precipitable water behavior in observations, reanalyses, and climate models, Mears et al. ${ }^{192}$ concluded that MSU but not reanalysis trend estimates are reasonable. Recently, Klotzbach et al. ${ }^{193}$ argued for the presence of an artificial warming in the land surface record in the tropics using only a subset 
of the available tropospheric records. As is the norm in scientific research and should be abundantly clear from the preceding sections, all these new analyses are likely to be reassessed and/or challenged by others over the coming years.

\section{SYNTHESIS AND CRITICAL ASSESSMENT}

The controversy that began in 1990 regarding differing rates of warming at the surface and in the troposphere spurred much focused research. In retrospect, it seems clear that the primary reason for the controversy was inadequate knowledge of the inherent uncertainties in estimates of temperature trends. These uncertainties are of two types: (1) structural uncertainties of the observed upper-air data; and (2) uncertainties due to the internal variability of the atmosphere, both observed and modeled.

At the start of the controversy there was only one upper-air temperature dataset each from satellites and radiosondes, and there was virtually no knowledge (or at least no acknowledgment in the literature) of the structural uncertainties that arise from attempting to create a climate data record from individual observations. The most crucial aspect is the process of homogenization, that is, attempting to remove the artificial effects of changing instruments and practices that are known or suspected to contaminate the record. The fundamental reason that the homogenization issue dominates this story is that historically we have lacked a global climate observing system-so that the only recourse is to try to use weather observations to assess climate changes.

The one satellite dataset available ${ }^{3}$ represented a pioneering effort and stimulated much vital research. However, as the initial team that produced this product, and other teams, further scrutinized the data, myriad confounding effects were revealed. This led to a number of dataset revisions and alternative datasets using different underlying methodologies (Figures 9 and 10).

The state of the radiosonde record was even more problematic as hardly any attempts at homogenization had been made during the first few decades (1970s-1990s) of analysis of radiosonde data for climate purposes. Throughout the 1990s researchers struggled just to uncover (but not remove) the problems in the data. Homogenization of radiosonde data is considerably more difficult than satellites because of greater unknowns regarding changes to the measurement system. Changes in radiosonde instruments and practices are often undocumented and overlap rarely exists. Furthermore, each radiosonde station usually has its own history, requiring a unique set of adjustments. Focusing on temperature anomalies at specific pressure levels, several homogenized radiosonde datasets have been produced over the past $5-10$ years.

Figure 10 shows the evolution of published temperature trends from 1979 to a given year between 1989 and 2008 for the surface and MT (which includes a $10-15 \%$ contribution from the cooling stratosphere, Figure 4), from both radiosonde and MSU data. For the UAH MSU data, the evolution of this trend using the September 2009 version is also shown for reference. For the surface temperatures it shows (1) very good agreement between the three analyses; and (2) the trend has remained quite stable over more than a decade. By contrast, the radiosonde analyses (1) differed considerably initially and, although they are in much better agreement now, differences remain; and (2) the trend changed from negative (cooling) to positive (warming), sometime in the early 2000s. For the MSU analyses (1) in the early part of the record there was much volatility in the trends from the UAH group and after 1997, when more analyses became available, there is considerable spread among the different analyses and little evidence of convergence over time, but (2) nevertheless the tendency toward all analyses showing a warming in the latter part of the record is clear. Additionally, there appears to be convergence of the surface and mid-troposphere trends in the latter part of the record. In summary, the most recent versions of all datasets do not support the conclusion of a significant difference in trend between the surface and troposphere when considering (1) the structural uncertainty (as evidenced by the spread) in the MT trend estimates, (2) the very likely remaining cold bias in the radiosonde trend estimates, and (3) the fact that the MT trend has a small stratospheric cooling component.

With regard to understanding internal variability of the Earth system, technological advances in computing power have greatly improved the ability to make model-based estimates. In 1990, only a few institutions had the resources to build, maintain and run GCMs capable of examining long-term changes, and they generally ran single model realisations. By contrast, today about 20 institutions maintain large-scale climate models, and ensembles of runs to characterize climate system variability are the norm.

Hence, there now exists a larger set of observational and model results, and these exhibit a degree of agreement, even in the tropics, where controversy has been greatest (Figures 7 and 8). 


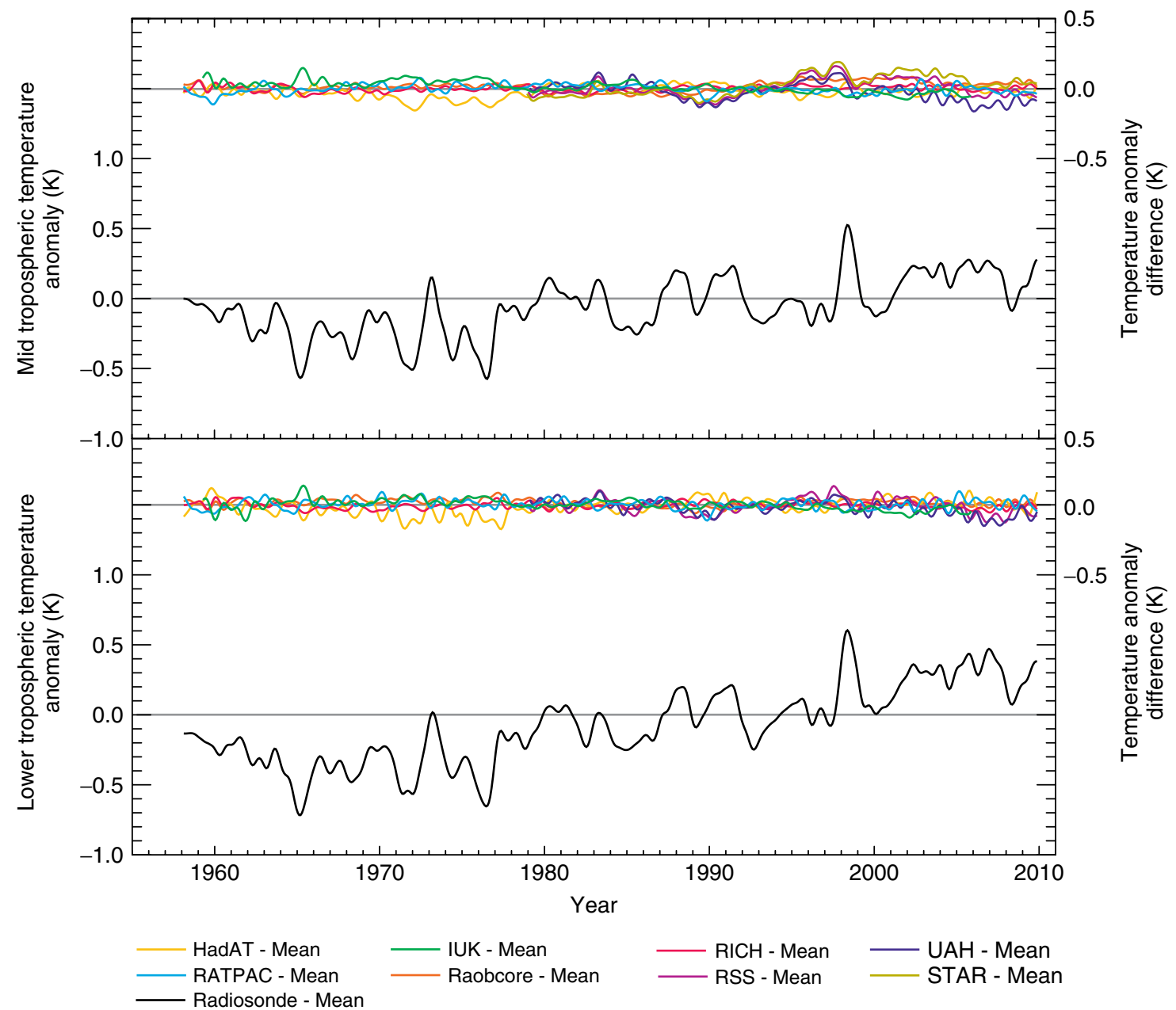

FIG URE 9 | Smoothed global-mean temperature anomalies for 1958-2009 based on radiosonde and MSU datasets for two layers (top MT; bottom LT). In each panel, the bottom trace is the average of five radiosonde datasets (HadAT, RATPAC, IUK, RAOBCORE, and RICH), and above are differences for individual datasets. Modified from State of the Climate in $2008^{194}$ and courtesy of Carl Mears, Remote Sensing Systems.

Supporting this broad perspective are important specific findings. Multiple lines of evidence suggest that many radiosonde datasets suffer from a bias toward excessive stratospheric cooling and insufficient tropospheric warming $59,114,120,165,166,169$ and that this bias is largest in the tropics, ${ }^{119,123}$ where the separation between the models and some of the radiosonde observations was largest. Further, independent wind measurements, ${ }^{169,171}$ physically-based arguments involving model-observational comparisons on short and long time scales, ${ }^{25,162}$ and explicit removal of stratospheric cooling effects from satellite tropical tropospheric trend estimates ${ }^{10}$ argue in favor of the consistency between modeled and observed trends.

Overall, there is now no longer reasonable evidence of a fundamental disagreement between models and observations with regard to the vertical structure of temperature change from the surface through the troposphere. ${ }^{2,191}$ This is mainly due to a much better understanding of the real level of uncertainty in estimates of past changes and expectations from climate models. Ironically, elucidation of the true (large) degree of uncertainty in actual trends from observations and expected trends from models has led to greater confidence that they are not inconsistent.

\section{CONCLUDING REMARKS}

There is an old saying that a person with one watch always knows what time it is, but with two watches one is never sure. The controversy over surface and tropospheric temperature trends started in 1990 when the first satellite upper air 'watch' was produced and it was naively assumed that it told the correct time. Over the subsequent years, with the advent 
FIGURE 10 | Evolution of estimates of observed trends in global-mean MT and surface temperatures during the satellite era (since 1979), based on satellite (blue), radiosonde (red) and land/SST (green) observations. Symbols show trends for 1979 to the year plotted, as reported in the literature, except for 1979-2008 trends which were calculated for this study (by Carl Mears or current authors). Blue line shows trends from the September 2009 version of UAH for each year. Differences between this line and the UAH published estimates (blue circles) illustrate the degree of change in the different versions of this dataset.

of not just two but multiple watches from different 'manufacturers' and using two distinct 'technologies', a more accurate measure of the structural uncertainty inherent in estimating what the 'time' truly is has emerged.

The state of the observational and model science has progressed considerably since 1990. The uncertainty of both models and observations is currently wide enough, and the agreement in trends close enough, to support a finding of no fundamental discrepancy between the observations and model estimates throughout the tropospheric column. However, the controversy will undoubtedly continue because some estimates of tropospheric warming since 1979 are less than estimates of surface warming, or fall outside of the range of analogous model estimates (e.g., Figure 8).

There are several key lessons for the future:

1. No matter how august the responsible research group, one version of a dataset cannot give a measure of the structural uncertainty inherent in the information.

2. A full measure of both observational uncertainty and model uncertainty must be taken into consideration when assessing whether there is agreement or disagreement between theory (as represented by models) and reality (as represented by observations).

3. In addition to better routine observations, underpinning reference observations are required to allow analysts to calibrate the data and unambiguously extract the true climate signal from the inevitable nonclimatic influences inherent in the routine observations. ${ }^{195}$

\section{ANNOTATED LIST OF ACRONYMS}

${ }^{*} \mathrm{G}$-layer for MSU observations derived by arithmetically removing the stratospheric influence on mid-tropospheric (MT) observations.

AMSU-Advanced Microwave Sounding Unit.

CARDS-Comprehensive Aerological Reference Dataset.

CCSP-U.S. Climate Change Science Program.

$\mathrm{CO}_{2}$ - carbon dioxide.

ECMWF-European Centre for Medium-Range Weather Forecasts.

ENSO-El Niño - Southern Oscillation.

GCM-general circulation model, also. sometimes global climate model

HadAT-Hadley Centre Atmospheric Temperatures, an adjusted radiosonde dataset.

HadCRUT3-Surface temperature dataset jointly prepared by the Hadley Centre and the Climatic Research Unit.

HadRT—Hadley Centre Radiosonde Temperature, an adjusted radiosonde dataset.

IGRA-NOAA NCDC Integrated Global Radiosonde Archive.

IPCC-Intergovernmental Panel on Climate Change.

IUK-Iterative Universal Kriging, a method to create an adjusted radiosonde dataset.

LECT-Local equatorial crossing time, at which a satellite passes overhead at the equator.

LKS-Lanzante, Klein, Seidel. An adjusted radiosonde dataset.

LS-Lower stratosphere. A broad layer sensed by Channel 4 of the MSU.

LT-Lower troposphere. A broad layer characterized by artificially combining Channel 2 measurements of the MSU. 
MSU-Microwave Sounding Unit.

MT-Middle troposphere.

NCDC-NOAA's National Climatic Data Center.

NOAA-U.S. National Oceanic and Atmospheric Administration.

NRC-U.S. National Research Council.

RAOBCORE-RAdiosonde OBservation COrrection using REanalyses, an adjusted radiosonde dataset.

RATPAC-Radiosonde Atmospheric Temperature Products for Climate, an adjusted radiosonde dataset.
RICH-Radiosonde Innovation Composite Homogenization, an adjusted radiosonde dataset.

RIHMI-All-Russian Research Institute of Hydrometeorological Information, developer of radiosonde data products.

RSS-Remote Sensing Systems, developer of a version of MSU data products.

SCEP-Study of Critical Environmental Problems, a 1970 assessment report.

SST-Sea Surface Temperature.

UAH-University of Alabama in Huntsville, developer of a version of MSU data products.

UMd-University of Maryland.

\section{ACKNOWLEDGEMENTS}

We thank Antonio Garcia (ECMWF); Kevin Linklater, and Fiona Carroll (U.K. Met Office); Sara Veasey, Deb Misch, Debi Riddle, and Glenn Hyatt (NOAA NCDC); and Carl Mears (Remote Sensing Systems) for help with sourcing and adapting many of the figures used herein. Mara Sprain (NOAA NCDC, STG Inc.) collated and formatted the reference list. We thank the anonymous reviewers. As internal or informal reviewers, Jim Angell, Melissa Free, Jana Goldman, Tom Knutson, L. Myles, David Parker, and Ron Stouffer helped to sharpen the text and ensure the inclusion of relevant work. PWT was supported by the Joint DECC and Defra Integrated Climate Programme-DECC/Defra (GA01101).

\section{REFERENCES}

1. Manabe S, Wetherald R. Thermal equilibrium of the atmosphere with a given distribution of relative humidity. J Atmos Sci 1967, 24:241-259.

2. Karl TR, Hassol SJ, Miller CD, Murray WL, eds. Temperature Trends in the Lower Atmosphere: Steps for Understanding and Reconciling Differences. Washington, DC: U.S. Climate Change Science Program and Subcommittee on Global Change Research; 2006, http://www.climatescience. gov/Library/sap/sap1-1/finalreport/default.htm.

3. Spencer RW, Christy JR. Precise monitoring of global temperature trends from satellites. Science 1990, 247:1558-1562.

4. National Research Council. Reconciling Observations of Global Temperature Change. Washington, DC: National Academy Press; 2000, 85.

5. Durre I, Vose RS, Wuertz DB. Overview of the integrated global radiosonde archive. J Clim 2006, 19:53-68.

6. Grant AN, Bronnimann S, Ewen T, Nagurny A. A new look at radiosonde data prior to 1958 . J Clim 2009, 22:3232-3247.

7. Thorne PW, Parker DE, Tett SFB, Jones PD, McCarthy M, Coleman H, Brohan P. Revisiting radiosonde upper air temperatures from 1958 to 2002. J Geophys Res 2005, 110:D18105. DOI:10.1029/2004JD005753.
8. Smith WL, Woolf HM, Hayden CM, Wark DQ, McMillan LM. The TIROS-N operational vertical sounder. Bull Amer Meteor Soc 1979, 60:1177-1187.

9. Spencer RW, Christy JR. Precision and radiosonde validation of satellite gridpoint temperature anomalies. Part II: A tropospheric retrieval and trends during 1979-90. J Clim 1992, 5:858-866.

10. Fu Q, Johanson CM, Warren SG, Seidel DJ. Contribution of stratospheric cooling to satellite-inferred tropospheric temperature trends. Nature 2004, 429:55-58.

11. Kalnay E, Kanamitsu M, Kistler R, Collins W, Deaven D, Gandin L, Iredell M, Saha S. White G, Woollen J, et al. The NCEP/NCAR 40-year reanalysis project. Bull Amer Meteor Soc 1996, 77:437-471.

12. Uppala SM, Kållberg PW, Simmons AJ, Andrae U, Da Costa Bechtold V, Fiorino M, Gibson JK, Haseler J, Hernandez A, Kelly GA, et al. The ERA40 re-analysis. Qtrly J Royal Meteor Soc 2005, 131:2961-3012.

13. Onogi K, Tsutsui J, Koide H, Sakamoto M, Kobayashi S, Hatsushika H, Matsumoto T, Yamazaki N, Kamahori H, Takahashi K, et al. The JRA-25 reanalysis. J Meteor Soc Japan 2007, $85: 369-432$

14. Graversen RG, Mauritsen T, Tjernström M, Källén E, Svensson G. Vertical structure of recent Arctic warming. Nature 2008, 451:53-56. 
15. Thorne PW. Arctic tropospheric warming amplification? Nature 2008, 455:E1-E2. DOI:10.1038/nature 07256.

16. Grant AN, Bronnimann S, Haimberger L. Recent Arctic warming vertical structure contested. Nature 2008, 455:E2-E3. DOI:10/1038/nature07257.

17. Bitz CM, Fu Q. Arctic warming aloft is data set dependent. Nature 2008, 455:E3-E4. DOI:10.1038/nature 07258 .

18. Christy JR, Seidel DJ, Sherwood SC. What kinds of atmospheric temperature variations can the current observing systems measure and what are their strengths and limitations, both spatially and temporally? In: Karl TR, Hassol SJ, Miller CD, Murray WL, eds. Temperature Trends in the Lower Atmosphere: Steps for Understanding and Reconciling Differences. Washington DC: U.S. Climate Change Science Program and the Subcommittee on Global Change Research; 2006, 29-46.

19. Thorne PW, Vose RS. Reanalyses suitable for characterizing long-term trends. Are they really achievable? Bull Amer Meteor Soc 2010, 91:353-361.

20. Bengtsson L, Hodges KI. On the evaluation of temperature trends in the tropical troposphere. Clim Dyn 2009. DOI:10.1007/s00382-009-0680-y.

21. Simmons AJ, Jones PD, Bechtold VD, Beljaars ACM, Kallberg PW, Saarinen S, Uppala SM, Viterbo P, Wedi N. Comparison of trends and low-frequency variability in CRU, ERA-40, and NCEP/NCAR analyses of surface air temperature. J Geophys Res 2004, 109:D24115. DOI:10.1029/2004JD005306.

22. Simmons AJ, Willett KM, Jones PD, Thorne PW, Dee D. Low-frequency variations in surface atmospheric humidity, temperature and precipitation: inferences from reanalyses and monthly gridded observational datasets. J Geophys Res 2010, 115:D01110. DOI:10.1029/2009JD012442.

23. Cubasch U, Cess RD. Processes and modelling. In: Houghton JT, Jenkins GJ, Ephraums JJ, eds. Climate Change: The IPCC Scientific Assessment. Cambridge, UK and New York, NY: Cambridge University Press; 1990, 69-91.

24. McAvaney BJ, Covey C, Joussaume S, Kattsov V, Kitho A, Ogana W, Pitman AJ, Weaver AJ, Wood RA, Zhao Z-C. Model evaluation. In: Houghton JT, Ding Y, Griggs DJ, Noguer M, van der Linden PJ, Dai X, Maskell K, Johnson CA, eds. Climate Change 2001: The Scientific Basis. Cambridge, UK and New York, NY: Cambridge University Press; 2001, 471-523.

25. Santer BD, Penner JE, Thorne PW. How well can the observed vertical temperature changes be reconciled with our understanding of the causes of these changes? In: Karl TR, Hassol SJ, Miller CD, Murray WL, eds. Temperature Trends in the Lower Atmosphere: Steps for Understanding and Reconciling
Differences. Washington, DC: U.S. Climate Change Science Program and the Subcommittee on Global Change Research; 2006, 89-118.

26. Le Treut H, Somerville R, Cubasch U, Ding Y, Mauritzen C, Mokssit A, Peterson T, Prather M. Historical overview of climate change science. In: Solomon S, Qin D, Manning M, Chen Z, Marquis M, Averyt KB, Tignor M, Miller HL, eds. Climate Change 2007: The Physical Science Basis. Cambridge, UK and New York, NY: Cambridge University Press; 2007, 93-127.

27. Manabe S, Wetherald RT. Effects of doubling $\mathrm{CO}_{2}$ concentration on climate of a general circulation model. J Atmos Sci 1975, 32:3-15.

28. Manabe S. Carbon dioxide and climate. Adv Geophys 1983, 25:39-82.

29. Manabe S, Stouffer RJ, Spelman MJ. Response of a coupled ocean-atmosphere model to increasing atmospheric carbon dioxide. Ambio 1994, 23:44-49.

30. Tett SFB, Mitchell JFB, Parker DE, Allen MR. Human influence on the atmospheric vertical temperature structure: detection and observations. Science 1996, 274:1170-1173.

31. Tett SFB, Jones GS, Stott PA, Hill DC, Mitchell JFB, Allen MR, Ingram WJ, Johns TC, Johnson CE, Jones A, et al. Estimation of natural and anthropogenic contributions to 20th century temperature change. J Geophys Res 2002, 107:4306. DOI:10.1029/2000JD000028.

32. Stott PA, Jones GS, Lowe JA, Thorne P, Durman CF, Johns TC, Thelen J-C. Transient climate simulations with the HadGEM1 climate model: causes of past warming and future climate change. J Clim 2006, 19:2763-2782.

33. Lorenz EN. Deterministic nonperiodic flow. J Atmos Sci 1963, 20:130-141.

34. Meehl GA, Boer GJ, Covey C, Latif M, Stouffer RJ. The coupled model intercomparison project (CMIP). Bull Amer Meteor Soc 2000, 81:313-318.

35. SCEP (Study of Critical Environmental Problems). In: Matthews WH, ed. Man's Impact on the Global Environment: Assessment and Recommendations for Action. Cambridge, MA: MIT Press; 1970, 319.

36. Ramanathan $\mathrm{V}$. The role of ocean-atmosphere interactions in the $\mathrm{CO}_{2}$ climate problem. J Atmos Sci 1981, 38:918-930.

37. Lindzen RS, Hou AY, Farrell BF. The role of convective model choice in calculating the climate impact of doubling $\mathrm{CO}_{2}$. J Atmos Sci 1982, 39:1189-1205.

38. Hansen J, Lacis A, Rind D, Russell L, Stone P, Fung I, Ruedy R, Lerner J. Climate sensitivity analysis of feedback mechanisms. In: Hansen J, Takahashi T, eds. Climate Processes and Climate Sensitivity. Washington, DC: American Geophysical Union; 1984, 130-163. 
39. Wetherald RT, Manabe S. An investigation of cloud cover change in response to thermal forcing. Clim Change 1986, 8:5-23.

40. Schlesinger M, Mitchell J. Climate model simulations of the equilibrium climatic response to increased carbon dioxide. Rev Geophys 1987, 25:760-798.

41. Angell JK, Korshover J. Estimate of the global change in tropospheric temperature between 1958 and 1973. Mon Wea Rev 1975, 103:1007-1012.

42. Angell JK, Korshover J. Estimate of global change in temperature, surface to $100 \mathrm{mb}$, between 1958 and 1975. Mon Wea Rev 1977, 105:375-385.

43. Oort AH. Global Atmospheric Circulation Statistics, 1958-1973. Washington DC: U.S. Government Printing Office; 1983, 180 [NOAA Professional Paper 14].

44. Angell JK. Variations and trends in tropospheric and stratospheric global temperatures, 1958-87. J Clim 1988, 12:1296-1313.

45. Parker DE. The influence of the Southern Oscillation and volcanic eruptions on temperature in the tropical troposphere. Int J Clim 1985, 5:273-282.

46. Peterson TC, Karl TR, Jamason PF, Knight R, Easterling DR. First difference method: maximizing station density for the calculation of long-term global temperature change. J Geophys Res 1998, 103:25967-25974.

47. Angell JK. Impact of El Niño on the delineation of tropospheric cooling due to volcanic eruptions. J Geophys Res 1988, 93:3697-3704.

48. Spencer RW, Christy JR, Grody NC. Global atmospheric temperature monitoring with satellite microwave measurements: method and results. J Clim 1990, 3:1979-1985.

49. Gary BL, Keihm SJ. Microwave sounding units and global warming. Science 1991, 251:316-317.

50. Spencer RW, Christy JR. Microwave sounding units and global warming: response. Science 1991, 251:317.

51. Folland CK, Karl T, Vinnikov KY. Observed climate variations and change. In: Houghton JT, Jenkins GJ, Ephraums JJ, eds. Climate Change: The IPCC Scientific Assessment. Cambridge, UK and New York, NY: Cambridge University Press; 1990, 195-238.

52. Epstein ES. Detecting climate change. J Appl Meteor 1982, 21:1172-1182.

53. Parker DE. On the detection of temperature changes induced by increasing atmospheric carbon dioxide. Qtrly J Royal Meteor Soc 1985, 111:587-601.

54. Karoly D. Northern hemisphere temperature trends: a possible greenhouse gas effect? Geophys Res Lett 1989, 16:465-468.

55. Karoly DJ. Southern hemsiphere temperature trends: a possible greenhouse gas effect? Geophys Res Lett 1987, 14:1139-1141.
56. Wigley TML, Barnett TP. Detection of the greenhouse effect in the observations. In: Houghton JT, Jenkins GJ, Ephraums JJ, eds. Climate Change: The IPCC Scientific Assessment. Cambridge, UK and New York, NY: Cambridge University Press; 1990, 239-255.

57. Oort AH, Liu HZ. Upper-air temperature trends over the globe. J Clim 1993, 6:1958-1989.

58. Parker D, Cox D. Towards a consistent global climatological rawinsonde data-base. Int J Clim 1995, 15:473-496.

59. Gaffen DJ. Temporal inhomogeneities in radiosonde temperature records. J Geophys Res 1994, 99:3667-3676.

60. Gaffen DJ. Historical Changes in Radiosonde Instruments and Practices: Instruments and Observing Methods. Geneva: World Meteorological Organization; 1993 [Report 50, WMO/TD-541].

61. Christy JR，Spencer RW， McNider RT. Reducing noise in the MSU daily lower tropospheric global temperature data set. J Clim 1995, 8:888-896.

62. Spencer RW, Christy JR. Precision and radiosonde validation of satellite gridpoint temperature anomalies. Part I: MSU channel 2. J Clim 1992, 5:847-857.

63. Spencer RW, Christy JR. Precision lower stratospheric temperature monitoring with the MSU: Technique, validation, and results 1979-1991. J Clim 1993, 6:1194-1204.

64. Christy JR, Drouilhet SJ. Variability in daily, zonal mean lower-stratospheric temperatures. J Clim 1994, $7: 106-120$.

65. Christy JR, Goodridge J. Precision global temperatures from satellites and urban warming effects of non-satellite data. Atmos Env 1995, 29:1957-1961.

66. Christy JR. Temperature above the surface layer. Clim Change 1995, 31:455-474.

67. Jones PD. Recent warming in global temperature series. Geophys Res Lett 1994, 21:1149-1152.

68. Christy JR, McNider RT. Satellite greenhouse signal. Nature 1994, 367:325.

69. Hansen J, Wilson H, Sato M, Ruedy R, Shah K, Hansen E. Satellite and surface temperature data at odds? Clim Change 1995, 30:103-117.

70. Karoly DJ, Cohen JA, Meehl GA, Mitchell JFB, Oort AH, Stouffer RJ, Wetherald RT. An example of fingerprint detection of greenhouse climate-change. Clim Dyn 1994, 10:97-105.

71. Santer BD, Taylor KE, Wigley TML, Johns TC, Jones PD, Karoly, DJ, Mitchell JFB, Oort AH, Penner JE, Ramaswamy V, et al. A search for human influences on the thermal structure of the atmosphere. Nature 1996, 382:39-46.

72. Nicholls N, Gruza GV, Jouzel J, Karl TR, Ogallo LA, Parker DE. Observed climate variability and change. In: Houghton JT, Meira Filho LG, Callander BA, Harris N, Kattenberg A, Maskell K, eds. Climate 
Change 1995: The Science of Climate Change. Cambridge, UK and New York, NY: Cambridge University Press; 1996, 133-192.

73. Santer BD, Wigley TML, Barnett TP, Anyamba E. Detection of climate change and attribution of causes. In: Houghton JT, Meira Filho LG, Callander BA, Harris N, Kattenberg A, Maskell K, eds. Climate Change 1995: The Science of Climate Change. Cambridge, UK and New York, NY: Cambridge University Press; 1996, 407-443.

74. Parker DE, Gordon M, Cullum DPN, Sexton DMH, Follard CK, Rayner N. A new global gridded radiosonde temperature data base and recent temperature trends. Geophys Res Lett 1997, 24:1499-1502.

75. Eskridge RE, Alduchov OA, Chernykh IV, Panmao Z, Polansky AC, Doty S. A Comprehensive Aerological Research Data Set (CARDS): rough and systematic errors. Bull Amer Meteor Soc 1995, 76:1759-1775.

76. Wallis T. A subset of core stations from the Comprehensive Aerological Reference Dataset (CARDS). J Clim 1998, 11:272-282.

77. Sterin AM, Eskridge RE. Monthly aerological data set: Some features and comparison of upper-air temperature data to the NCAR/NCEP reanalysis monthly data. Proceedings of the 22nd Annual Climate Diagnostics and Prediction Workshop: 6-10 October 1997, Berkeley. Silver Spring MD: National Oceanic and Atmospheric Administration; 1998, 210-213.

78. Sterin AM. An analysis of linear trends in the free atmosphere temperature series for 1958-1997 (in Russian). Meteor Gidrol 1999, 5:52-68.

79. Angell JK. Comparison of surface and tropospheric temperature trends estimated from a 63-station radiosonde network, 1958-1998. Geophys Res Lett 1999, 26:2761-2764.

80. Angell JK. Difference in radiosonde temperature trend for the period 1979-1998 of MSU data and the period 1959-1998 twice as long. Geophys Res Lett 2000, 27:2177-2180.

81. Luers JK, Eskridge RE. Use of radiosonde temperature data in climate studies. J Clim 1998, 11:1002-1019.

82. Durre I, Peterson TC, Vose RS. Evaluation of the Luers-Eskridge homogeneity adjustments to radiosonde temperature measurements. J Clim 2002, 15:1335-1347.

83. Gaffen DJ, Sargent MA, Habermann RE, Lanzante JR. Sensitivity of tropospheric and stratospheric temperature trends to radiosonde data quality. J Clim 2000, 13:1776-1796.

84. Christy JR, Spencer RW, Lobl ES. Analysis of the merging procedure for the MSU daily temperature time series. J Clim 1998, 11:2016-2041.

85. Christy JR, Spencer RW, Braswell WD. MSU tropospheric temperatures: Dataset construction and radiosonde comparisons. J Atmos Ocean Tech 2000, 17:1153-1170.
86. Mo T. A study of the microwave sounding unit on the NOAA-12 satellite. IEEE Trans Geosci Remote Sens 1995, 33:1141-1152.

87. Wentz FJ, Schabel M. Effects of satellite orbital decay on MSU lower tropospheric temperature trends. Nature 1998, 394:661-664.

88. Prabhakara C, Iacovazzi R. Comments on "Analysis of the merging procedure for the MSU daily temperature time series". J Clim 1999, 12:3331-3334.

89. Prabhakara C, Iacovazzi R, Yoo J-M, Dalu G. Global warming: evidence from satellite observations. Geophys Res Lett 2000, 27:3517-3520.

90. Gaffen DJ. Falling satellites, rising temperatures? Nature 1998, 394:615-616.

91. Gee H. Satellite climate record in error. Nature 1998, DOI:10.1038/news980820-1.

92. Hansen JE, Sato M, Ruedy R, Lacis A, Glascoe J. Global climate data and models: reconciliation. Science 1998, 281:930-932.

93. Kerr R. Among global thermometers, warming still wins out. Science 1998, 281:1948-1949.

94. Prabhakara C, Iacovazzi R, Yoo J-M, Dalu G. Global warming deduced from MSU. Geophys Res Lett 1998, 25:1927-1930.

95. Hurrell JW, Trenberth KE. Spurious trends in satellite MSU temperatures from merging different satellite records. Nature 1997, 386:164-167.

96. Hurrell JW, Trenberth KE. Difficulties in obtaining reliable temperature trends: reconciling the surface and satellite MSU 2R trends. J Clim 1998, 11:945-967.

97. Trenberth KE, Hurrell JW. Response to "How accurate are satellite 'thermometers'?”. Nature 1997, 389:342-343.

98. Jones PD, Osborn TJ, Wigley TML, Kelly PM, Santer BD. Comparisons between the MSU 2R temperature record and the surface temperature record over 1979 to 1996: real differences or potential discontinuities? J Geophys Res 1997, 102:30135-30145.

99. Christy JR, Spencer RW, Braswell WD. How accurate are satellite 'thermometers'? Nature 1997, 389:342-343.

100. Allen MR, Tett SFB. Checking for model consistency in optimal fingerprints. Clim Dyn 1999, 15:419-434.

101. Gillett NP, Allen MR, Tett SFB. Modelled and observed variability in atmospheric vertical temperature structure. Clim Dyn 2000, 16:49-61.

102. Folland CK, Sexton DMH, Karoly DJ, Johnson CE, Rowell DP, Parker DE. Influences of anthropogenic and oceanic forcing on recent climate change. Geophys Res Lett 1998, 25:353-356.

103. Hurrell JW, Trenberth KE. Satellite versus surface estimates of air temperature since 1979. J Clim 1996, 9:2222-2232. 
104. Hurrell JW, Brown SJ, Trenberth KE， Christy JR. Comparison of tropospheric temperatures from radiosondes and satellites: 1979-98. Bull Amer Meteor Soc 2000, 81:2165-2177.

105. Folland CK, Karl TR, Christy JR, Clarke RA, Gruza GV, Jouzel J, Mann ME, Oerlemans J, Salinger MJ, Wang S-W. Observed climate variability and change. In: Houghton JT, Ding Y, Griggs DJ, Noguer M, van der Linden PJ, Dai X, Maskell K, Johnson CA, eds. Climate Change 2001: The Scientific Basis. Cambridge, UK and New York, NY: Cambridge University Press; 2001, 99-181.

106. Santer BD, Hnilo JJ, Wigley TML, Boyle JS, Doutriaux C, Fiorino M, Parker DE, Taylor KE. Uncertainties in observationally based estimates of temperature change in the free atmosphere. J Geophys Res 1999, 104:6305-6333.

107. Santer BD, Wigley TML, Boyle JS, Gaffen DJ, Hnilo JJ, Nychka D, Parker DE, Taylor KE. Statistical significance of trends and trend differences in layer-average atmospheric temperature time series. J Geophys Res 2000, 105:7337-7356.

108. Stendel M, Christy JR, Bengtsson L. Assessing levels of uncertainty in recent temperature time series. Clim Dyn 2000, 16:587-601.

109. Gaffen DJ, Santer BD, Boyle JS, Christy JR, Graham NE, Ross RJ. Multidecadal changes in the vertical temperature structure of the tropical troposphere. Science 2000, 287:1242-1245.

110. Brown SJ, Parker DE, Folland CK, Macadam I. Decadal variability in the lower-tropospheric lapse rate. Geophys Res Lett 2000, 27:997-1000.

111. Mitchell JFB, Karoly DJ, Hegerl GC, Zwiers FW, Allen MR, Marengo J. Detection of climate change and attribution of causes. In: Houghton JT, Ding Y, Griggs DJ, Noguer M, van der Linden PJ, Dai X, Maskell K, Johnson CA, eds. Climate Change 2001: The Scientific Basis. Cambridge, UK and New York, NY: Cambridge University Press; 2001, 695-738.

112. Free M, Durre I, Aguilar E, Seidel D, Peterson TC, Eskridge RE, Luers JK, Parker D, Gordon M, Lanzante J, et al. Creating climate reference datasets: CARDS workshop on adjusting radiosonde temperature data for climate monitoring. Bull Amer Meteor Soc 2002, 83:891-899.

113. Lanzante JR, Klein SA, Seidel DJ. Temporal homogenization of monthly radiosonde temperature data. Part I: Methodology. J Clim 2003, 16:224-240.

114. Lanzante JR, Klein SA, Seidel DJ. Temporal homogenization of monthly radiosonde temperature data. Part II: Trends, sensitivities, and MSU comparison. J Clim 2003, 16:241-262.

115. Free M, Angell JK, Durre I, Lanzante JR, Peterson TC, Seidel DJ. Using first differences to reduce inhomogeneity in radiosonde temperature datasets. J Clim 2004, 17:4171-4179.
116. Free M, Seidel DJ, Angell JK, Lanzante JR, Durre I, Peterson TC. Radiosonde Atmospheric Temperature Products for Assessing Climate (RATPAC): a new data set of large-area anomaly time series. J Geophys Res 2005, 110:D22101. DOI:10.1029/2005JD006169.

117. Eskridge RE, Luers JK, Redder CR. Unexplained discontinuity in the U.S. radiosonde temperature data. Part I: Troposphere. J Clim 2003, 16:2385-2395.

118. Redder CR, Luers JK, Eskridge RE. Unexplained discontinuity in the U.S. radiosonde temperature data. Part II: Stratosphere. J Atmos Ocean Tech 2004, 21:1133-1144.

119. Sherwood SC, Lanzante JR, Meyer CL. Radiosonde daytime biases and late-20th century warming. Science 2005, 309:1556-1559.

120. Randel W, Wu F. Biases in stratospheric and tropospheric temperature trends derived from historical radiosonde data. J Clim 2006, 19:2094-2104.

121. Randel W, Wu F. Reply to comments on "Biases in stratospheric and tropospheric temperature trends derived from historical radiosonde data". J Clim 2007, 20:3710-3711.

122. Free M, Seidel DJ. Comments on "Biases in stratospheric and tropospheric temperature trends derived from historical radiosonde data". J Clim 2007, 20:3704-3709.

123. Angell JK. Effect of exclusion of anomalous tropical stations on temperature trends from a 63-station radiosonde network, and comparison with other analyses. J Clim 2003, 16:2288-2295.

124. Christy JR, Spencer RW, Norris WB, Braswell WD, Parker DE. Error estimates of version 5.0 of MSUAMSU bulk atmospheric temperatures. J Atmos Ocean Tech 2003, 20:613-629.

125. Mears CA, Schabel MC, Wentz FJ. A reanalysis of the MSU channel 2 tropospheric temperature record. J Clim 2003, 16:3650-3664.

126. Mears CA, Wentz FJ. The effect of diurnal correction on satellite-derived lower tropospheric temperature. Science 2005, 309:1548-1551.

127. Christy JR, Spencer RW. Correcting temperature data sets. Science 2005, 310:972.

128. Vinnikov KY, Grody NC. Global warming trend of mean tropospheric temperature observed by satellites. Science 2003, 302:269-272.

129. Grody NC, Vinnikov KY, Goldberg MD, Sullivan JT, Tarpley JD. Calibration of multisatellite observations for climatic studies: Microwave Sounding Unit (MSU). J Geophys Res 2004, 109:D24104. DOI:10.1029/2004JD005079.

130. Vinnikov KY，Grody NC， Robock A， Stouffer RJ, Jones PD, Goldberg MD. Temperature trends at the surface and in the troposphere. J Geophys Res 2006, 111:D03106. DOI:10.1029/2005JD006392.

131. Christy JR, Norris WB. What may we conclude about global tropospheric temperature 
trends? Geophys Res Lett 2004, 31:L06211. DOI:10.1029/2003GL019361.

132. Mears CA, Forest CE, Spencer RW, Vose RS, Reynolds RW. What is our understanding of the contribution made by observational or methodological uncertainties to the previously reported vertical differences in temperature trends? In: Karl TR, Hassol SJ, Miller CD, Murray WL, eds. Temperature Trends in the Lower Atmosphere: Steps for Understanding and Reconciling Differences. Washington, DC: U.S. Climate Change Science Program and the Subcommittee on Global Change Research; 2006, 71-88.

133. Thorne PW, Parker DE, Christy JR, Mears CA. Uncertainties in climate trends-lessons from upper-air temperature records. Bull Amer Meteor Soc 2005, 86:1437-1442.

134. Swanson RE. Evidence of possible sea-ice influence on microwave sounding unit tropospheric temperature trends in polar regions. Geophys Res Lett 2003, 30:2040. DOI:10.1029/2003GL017938.

135. Fu Q, Seidel DJ, Johanson CM, Warren SG. Atmospheric science: stratospheric cooling and the troposphere (reply). Nature 2004, 432:E2-E3. DOI:10/1038/nature03210.

136. Fu Q, Johanson CM. Stratospheric influence on MSUderived tropospheric temperature trends: a direct error analysis. J Clim 2004, 17:4636-4640.

137. Fu Q, Johanson CM. Satellite-derived vertical dependence of tropical tropospheric temperature trends. Geophys Res Lett 2005, 32:L10703. DOI:10.1029/2004GL022266.

138. Johanson CM, Fu Q. Robustness of tropospheric temperature trends from MSU channels 2 and 4. J Clim 2006, 19:4234-4242.

139. Tett S, Thorne P. Tropospheric temperature series from satellites. Nature 2004, 432:E1. DOI:10.1038/ nature 03208 .

140. Gillett NP, Santer BD, Weaver AJ. Stratospheric cooling and the troposphere. Nature 2004, 432:E1-E2. DOI:10.1038/nature03209.

141. Kiehl JT, Caron JM, Hack JJ. On using global climate model simulations to assess the accuracy of MSU retrieval methods for tropospheric warming trends. J Clim 2005, 18:2533-2539.

142. Spencer RW, Christy JR, Braswell WD, Norris WB. Estimation of tropospheric temperature trends from MSU Channels 2 and 4. J Ocean Atmos Tech 2006, 23:417-423.

143. Seidel DJ, Angell JK, Christy J, Free M, Klein SA, Lanzante JR, Mears C, Parker D, Schabel M, Spencer R, et al. Uncertainty in signals of large-scale climate variations in radiosonde and satellite upper-air temperature datasets. J Clim 2004, 17:2225-2240.

144. Christy JR, Parker DE, Brown SJ, Macadam I, Stendel M, Norris WB. Differential trends in tropical sea surface and atmospheric temperature since 1979. Geophys Res Lett 2001, 28:183-186.

145. Agudelo PA, Curry JA. Analysis of spatial distribution in tropospheric temperature trends. Geophys Res Lett 2004, 31:L22207. DOI:10.1029/2004GL02818.

146. Free M, Seidel DJ. Causes of differing temperature trends in radiosonde upper air data sets. J Geophys Res 2005, 110:D07101. DOI:10.1029/2004JD005481.

147. Lanzante JR, Peterson TC, Wentz FJ, Vinnikov KY. What do observations indicate about the change of temperatures in the atmosphere and at the surface since the advent of measuring temperatures vertically? In: Karl TR, Hassol SJ, Miller CD, Murray WL, eds. Temperature Trends in the Lower Atmosphere: Steps for Understanding and Reconciling Differences. Washington DC: U.S. Climate Change Science Program and the Subcommittee on Global Change Research; 2006, 47-70.

148. Hegerl G, Wallace J. Influence of patterns of climate variability on the difference between satellite and surface temperature trends. J Clim 2002, 15:2412-2428.

149. Sexton DMH, Rowell DP, Folland CK, Karoly DJ. Detection of anthropogenic climate change using an atmospheric GCM. Clim Dyn 2001, 17:669-685.

150. Hill DC, Allen MR, Stott PA. Allowing for solar forcing in the detection of human influence on tropospheric temperatures. Geophys Res Lett 2001, 28:1555-1558.

151. Thorne PW, Jones PD, Osborn TJ, Davies TD, Tett SFB, Parker DE, Stott PA, Jones GS, Allen MR. Assessing the robustness of zonal mean climate change detection. Geophys Res Lett 2002, 29:1920. DOI:10.1029/2002GL015717.

152. Thorne PW, Jones PD, Tett SFB, Allen MR, Parker DE, Stott PA, Jones GS, Osborn TJ, Davies TD. Probable causes of late twentieth century tropospheric temperature trends. Clim Dyn 2003, 21:573-591.

153. Jones GS, Tett SFB, Stott PA. Causes of atmospheric temperature change 1960-2000: A combined attribution analysis. Geophys Res Lett 2003, 30:1228. DOI:10.1029/2002GL016377.

154. Legates DR, Davies RE. The continuing search for an anthropogenic climate change signal: limitations of correlation-based approaches. Geophys Res Lett 1997, 24:2319-2322.

155. Hansen J, Sato M, Nazarenko L, Ruedy R, Lacis A, Koch D, Tegen I, Hall T, Shindell D, Santer B, et al. Climate forcings in Goddard Institute for Space Studies SI2000 simulations. J Geophys Res 2002, 107:4347. DOI:10.1029/2001JD001143.

156. Michaels PJ, Knappenberger PC. Natural signals in the MSU lower tropospheric temperature record. Geophys Res Lett 2000, 27:2905-2908.

157. Santer BD, Wigley TML, Doutriaux C, Boyle JS, Hansen JE, Jones PD, Meehl GA, Roeckner E, Sengupta S, Taylor KE. Accounting for the effects of 
volcanoes and ENSO in comparisons of modeled and observed temperature trends. J Geophys Res 2001, 106:28033-28059.

158. Douglass DH, Pearson BD, Singer SF, Knappenberger PC, Michaels PJ. Disparity of tropospheric and surface temperature trends: new evidence. Geophys Res Lett 2004, 31:L13207. DOI:10.1029/ 2004GL020212.

159. Douglass DH, Pearson BD, Singer SF. Altitude dependence of atmospheric temperature trends: climate models versus observation. Geophys Res Lett 2004, 31:L13208. DOI:10.1029/2004GL020103.

160. Lindzen RS, Giannitsis C. Reconciling observations of global temperature change. Geophys Res Lett 2002, 29:1583. DOI:10.1029/2001GL014074.

161. Santer BD, Wigley TML, Meehl GA, Wehner MF, Mears C, Schabel M, Wentz FJ, Ammann C, Arblaster J, Bettge T, et al. Influence of satellite data uncertainties on the detection of externally forced climate change. Science 2003, 300:1280-1284.

162. Santer BD, Wigley TML, Mears C, Wentz FJ, Klein SA, Seidel DJ, Taylor KE, Thorne PW, Wehner MF, Gleckler PJ, et al. Amplification of surface temperature trends and variability in the tropical atmosphere. Science 2005, 309:1551-1556.

163. Trenberth KE, Jones PD, Ambenje P, Bojariu R, Easterling D, Klein Tank A, Parker D, Rahimzadeh F, Renwick JA, Rusticucci M, et al. Observations: surface and atmospheric climate change. In: Solomon S, Qin D, Manning M, Chen Z, Marquis M, Averyt KB, Tignor M, Miller HL, eds. Climate Change 2007: The Physical Science Basis. Cambridge, UK and New York, NY: Cambridge University Press; 2007, 235-336.

164. Hegerl GC, Zwiers FW, Braconnot P, Gillett NP, Luo Y, Marengo Orsini JA, Nicholls N, Penner JE, Stott PA. Understanding and attributing climate change. In: Solomon S, Qin D, Manning M, Chen Z, Marquis M, Averyt KB, Tignor M, Miller HL, eds. Climate Change 2007: The Physical Science Basis. Cambridge, UK and New York, NY: Cambridge University Press; 2007, 663-745.

165. McCarthy MP, Titchner HA, Thorne PW, Tett SFB, Haimberger L, Parker DE. Assessing bias and uncertainty in the HadAT adjusted radiosonde climate record. J Clim 2008, 21:817-832.

166. Titchner HA, Thorne PW, McCarthy MP, Tett SFB, Haimberger L, Parker DE. Critically assessing tropospheric temperature trends from radiosondes using realistic validation experiments. J Clim 2009, 22:465-485.

167. Haimberger L. Homogenization of radiosonde temperature time series using innovation statistics. J Clim 2007, 20:1377-1403.

168. Haimberger L, Tavolato C, Sperka S. Toward elimination of the warm bias in historic radiosonde temperature records-some new results from a comprehensive intercomparison of upper-air data. J Clim 2008, 21:4587-4606.

169. Sherwood SC, Meyer CL, Allen RJ, Titchner HA. Robust tropospheric warming revealed by interatively homogenised radiosonde data. J Clim 2008, 21:5336-5352.

170. Allen RJ, Sherwood SC. Utility of radiosonde wind data in representing climatological variations of tropospheric temperature and baroclinicity in the western tropical Pacific. J Clim 2007, 20:5229-5243.

171. Allen RJ, Sherwood SC. Warming maximum in the tropical upper troposphere deduced from thermal winds. Nat Geosci 2008, 1:399-403.

172. Thorne PW. Atmospheric science-the answer is blowing in the wind. Nat Geosci 2008, 1:347-348.

173. Gruber C, Haimberger L. On the homogeneity of radiosonde wind time series. Meteor Zeit 2008, 17:631-643.

174. Schleip C, Menzel A, Dose V. Bayesian analysis of changes in radiosonde atmospheric temperature. Int J Clim 2009, 29:629-641.

175. Seidel DJ, Lanzante JR. An assessment of three alternatives to linear trends for characterizing global atmospheric temperature changes. Geophys Res Lett 2004, 109:D14108. DOI:10.1029/2003JD004414.

176. Mears CA, Wentz FJ. Construction of the Remote Sensing Systems V3.2 atmospheric temperature records from the MSU and AMSU microwave sounders. J Atmos Ocean Tech 2009, 26:1040-1056.

177. Mears CA, Wentz FJ. Construction of the RSS V3.2 lower tropospheric temperature dataset from the MSU and AMSU microwave sounders. J Atmos Ocean Tech 2009, 26:1493-1509.

178. Zou C-Z, Goldberg MD, Cheng Z, Grody NC, Sullivan JT, Cao C, Tarpley D. Recalibration of microwave sounding unit for climate studies using simultaneous nadir overpasses. J Geophys Res 2006, 111:D19114. DOI:10.1029/2005JD006798.

179. Zou C-Z, Gao M, Goldberg MD. Error structure and atmospheric temperature trends in observations from the microwave sounding unit. J Clim 2009, 22:1661-1681.

180. Brohan P, Kennedy JJ, Harris I, Tett SFB, Jones PD. Uncertainty estimates in regional and global observed temperature changes: a new dataset from 1850. J Geophys Res 2006, 111:D12106. DOI:10.1029/2005JD006548.

181. Christy JR, Norris WB. Satellite and VIZ-radiosonde intercomparison for diagnosis of nonclimatic influences. J Atmos Ocean Tech 2006, 23:1181-1194.

182. Christy JR, Norris WB, Spencer RW, Hnilo JJ. Tropospheric temperature change since 1979 from tropical radiosonde and satellite measurements. J Geophys Res 2007, 112:D06102. DOI:10.1029/2005JD006881. 
183. Christy JR, Norris WB. Discontinuity issues with radiosonde and satellite temperatures in the Australian region 1979-2006. J Atmos Ocean Tech 2009, 26:508-522.

184. Randall RM, Herman BM. Using limited time period trends as a means to determine attribution of discrepancies in microwave sounding unit-derived tropospheric temperature time series. J Geophys Res 2008, 113:D05105. DOI:10.1029/2007JD008864.

185. Lanzante JR. Diagnosis of radiosonde vertical temperature trend profiles: comparing the influence of data homogenization versus model forcings. J Clim 2007, 20:5356-5364.

186. Lanzante JR, Free M. Comparison of radiosonde and GCM vertical temperature trend profiles: Effects of dataset choice and data homogenization. J Clim 2008, 21:5417-5435.

187. Forster PM, Bodeker G, Schofield R, Solomon S. Effects of ozone cooling in the tropical lower stratosphere and upper troposphere. Geophys Res Lett 2007, 34:L23813. DOI:10.1029/2007GL031994.

188. Thorne PW, Parker DE, Santer BD, McCarthy MP, Sexton DMH, Webb MJ, Murphy JM, Collins M, Titchner HA, Jones GS. Tropical vertical temperature trends. A real discrepancy? Geophys Res Lett 2007, 34:L16702. DOI:10.1029/2007GL029875.

189. Murphy JM, Sexton DMH, Barnett DN, Jones GS, Webb MJ, Collins M, Stainforth DA. Quantification of modelling uncertainties in a large ensemble of climate change simulations. Nature 2004, 430:768-772.

190. Douglass DH, Christy JR, Pearson BD, Singer SF. A comparison of tropical temperature trends with model predictions. Int J Climatol 2008, 27:1693-1701.

191. Santer BD, Thorne PW, Haimberger L, Taylor KE, Wigley TML, Lanzante JR, Solomon S, Free M, Gleckler PJ, Jones PD, et al. Consistency of modelled and observed temperature trends in the tropical troposphere. Int J Climatol 2008, 28:1703-1722.

192. Mears CA, Santer BD, Wentz FJ, Taylor KE, Wehner MF. Relationship between temperature and precipitable water changes over tropical oceans. Geophys Res Lett 2007, 34:L24709. DOI:10.1029/ 2007 GL031936.

193. Klotzbach PJ, Pielke RA Sr., Pielke RA Jr., Christy JR, McNider RT. An alternative explanation for differential temperature trends at the surface and in the lower troposphere. J Geophys Res 2009, 114:D21102. DOI:10.1029/2009JD011841.

194. Peterson TC, Baringer MO, eds. State of the climate in 2008. Bull Amer Meteor Soc 2009, 90:S1-S196.

195. Seidel DJ, Berger FH, Immler F, Sommer M, Vömel H, Diamond HJ, Dykema J, Goodrich D, Murray W, Peterson T, et al. Reference upper-air observations for climate: rationale, progress, and plans. Bull Amer Meteor Soc 2009, 90:361-369. 